\title{
In Vitro Study of the Nephrotoxicity of Tripterygium Tablet Extract and Triptolide in Monolayer HK-2 Cells Cultured in a Transwell Chamber
}

\author{
Ran Hao, Lianqiang Hui, Chun Li, Chunyu Cao, Yifei Yang, Jiyuan Zhang, Ting Liu*, Yi Zhang \\ Institute of Chinese Materia Medica, China Academy of Chinese Medical Sciences, Beijing, China \\ Email: ^ltbit@163.com
}

How to cite this paper: Hao, R., Hui, L.Q., Li, C., Cao, C.Y., Yang, Y.F., Zhang, J.Y., Liu, T. and Zhang, Y. (2018) In Vitro Study of the Nephrotoxicity of Tripterygium Tablet Extract and Triptolide in Monolayer HK-2 Cells Cultured in a Transwell Chamber. Chinese Medicine, 9, 34-54.

https://doi.org/10.4236/cm.2018.91003

Received: December 12, 2017

Accepted: March 11, 2018

Published: March 14, 2018

Copyright $\odot 2018$ by authors and Scientific Research Publishing Inc. This work is licensed under the Creative Commons Attribution International License (CC BY 4.0).

http://creativecommons.org/licenses/by/4.0/

\begin{abstract}
We established a monolayer polarized cell model using human kidney 2 (HK-2) cells cultured in a transwell chamber to examine the changes in the morphology and physiological functions of human-derived renal proximal tubular epithelial cells caused by tripterygium tablet extract (TTE) and triptolide. HK-2 cells were cultured on PCF membranes to form a complete monolayer of cells. A MTT assay was used to select $10,40,160,640 \mu \mathrm{g} \cdot \mathrm{ml}^{-1}$ TTE or 4, 16, 64, $256 \mathrm{ng} \cdot \mathrm{ml}^{-1}$ triptolide to treat HK-2 monolayer cells. After 24 hours, a FITC permeability assay was performed; GGT, LDH and NAG secretion on the apical (AP) and basolateral (BL) sides of the cells by HK-2 cells were examined. The morphology and the monolayer structure of HK-2 cells was observed via optical microscope and scanning electron microscope, respectively. The effect on the cytoskeleton of HK-2 cells was observed under a fluorescence microscope. The $\mathrm{IC}_{50}$ of TTE was $277.122 \mu \mathrm{g} \cdot \mathrm{ml}^{-1}$, and the $\mathrm{IC}_{50}$ of triptolide was $148.035 \mathrm{ng} \cdot \mathrm{ml}^{-1}$. Compared with the DMSO group, the FITC leakage rate with TTE $160,640 \mu \mathrm{g} \cdot \mathrm{ml}^{-1}$ treated group and $4-256 \mathrm{ng} \cdot \mathrm{ml}^{-1}$ triptolide dose group exhibited statistically significant increase. TTE significantly increased secretion of GGT and LDH at $160,640 \mu \mathrm{g} \cdot \mathrm{ml}^{-1}$, meanwhile, dramatically increased the AP/BL ratio of LDH at $160 \mu \mathrm{g} \cdot \mathrm{ml}^{-1}$; triptolide significantly increased secretion and AP/BL ratio of GGT and LDH at $256 \mathrm{ng} \cdot \mathrm{ml}^{-1}$. The morphological observations via optical and electron microscope indicated various degrees of damage to HK-2 cells by TTE and triptolide, and the degree of damage correlated positively with the dosage of the tested articles. Compared with DMSO group, the cellular damage degrees at TTE dosages of 40 $640 \mu \mathrm{g} \cdot \mathrm{ml}^{-1}$ and triptolide dose group at $16,256 \mathrm{ng} \cdot \mathrm{ml}^{-1}$ exhibited statistically significant differences via observation under optical microscope. Both TTE
\end{abstract}


and triptolide caused various degrees of shortening and thickening of intracellular F-actin bundles of HK-2 cells; aggravation of these changes was observed with increasing drug dosage. Thus, we conclude both TTE and triptolide caused damage to human renal proximal tubular epithelial cells at certain dosages; TTE dosages of $40 \mu \mathrm{g} \cdot \mathrm{ml}^{-1}$ and above and triptolide dose group at 16 $\mathrm{ng} \cdot \mathrm{ml}^{-1}$ and above exhibited the changes in the morphology, meanwhile, TTE dosages of $160 \mu \mathrm{g} \cdot \mathrm{ml}^{-1}$ and above and triptolide dose group at $256 \mathrm{ng} \cdot \mathrm{ml}^{-1} \mathrm{ex}$ hibited the changes in the physiological functions such as secretion of HK-2 cell.

\section{Keywords}

Nephrotoxicity, Tripterygium Tablet Extract, Triptolide, HK-2 Cell, Transwell Chamber

\section{Introduction}

Tripterygium wilfordii Hook.f. is an annual woody vine of the genus Tripterygium in the Celastraceae family. Its efficacy was initially recorded in "Southern Yunnan Materia Medica" by Mao Lan in the Ming Dynasty. Tripterygium wilfordii Hook.f. has a history of medical use of nearly 700 years and has shown effects in promoting blood circulation, removing blood stasis, heat-clearing, detoxicating, reducing swelling, resolving masses, killing pests and stopping bleeding. Modern pharmacological and clinical studies have confirmed that Tripterygium wilfordii has a variety of pharmacological effects, such as anti-inflammatory and immunosuppressive effects and changing the rheological properties of blood. It has been mainly used for the treatment of rheumatoid arthritis, nephrotic syndrome, systemic lupus erythematosus and other autoimmune diseases and has demonstrated therapeutic effects. However, its application has been limited by adverse reactions, including unambiguous liver, kidney and reproductive toxicity and damage to the bone marrow, hematological system and gastrointestinal system. Determination of a method to reduce or eliminate its toxicity without affecting its efficacy has been a focus of research [1] [2] [3].

Tripterygium tablet is a table consisting fat-soluble mixture extracted from the root of Tripterygium wilfordii, an anti-inflammatory and immunomodulatory traditional Chinese herbal medicine that was first studied and used in China, also called as the "herbal hormone" [4]. Studies have suggested that the alkaloids, diterpenes, triterpenes and glycosides in Tripterygium wilfordii have certain toxicity, ranging from high to low in the following order: diterpenes, alkaloids, triterpenes and glycosides [5]. A toxicity study of total glycosides showed that the degree and affected area of the damage caused by total glycosides were much smaller than those of the crude herbal medicine or the alkaloids [2]. Tripterygium tablet had been shown to be effective and safe for the treatment of proteinuria in elderly patients with kidney diseases [6]. Triptolide is a diterpenoid 
that belongs to the tricyclic diterpene epoxide category (or triptolide derivatives) and shows a highly effective broad-spectrum antitumor activity. Triptolide is the most active epoxide diterpene lactone in Tripterygium wilfordii; however, it is also the main ingredient of Tripterygium wilfordii that causes the adverse effects [7]. In mice administered triptolide, the $\mathrm{LD}_{50}$ was $0.725 \mathrm{mg} / \mathrm{kg}$ for intraperitoneal administration and $0.788 \mathrm{mg} / \mathrm{kg}$ for oral administration; toxicity was induced in the heart, liver, bone marrow, thorax, spleen, kidney and reproductive system [8] [9]. Renal toxicity is manifested as rapid or gradual occurrence of oliguria, edema, hematuria, proteinuria and cylindruria after triptolide use. Drug-induced acute renal insufficiency, drug-induced acute interstitial nephritis and even acute renal failure may occur in severe cases [10]. The mechanism underlying the renal toxicity is likely related to the direct toxic effects of Tripterygium wilfordii and the renal tubular epithelial cell degeneration and necrosis caused by renal ischemia [11]. Determination of a method to expand the clinical application of Tripterygium wilfordii by reducing its toxicity while preserving its efficacy has become an important issue in research regarding Tripterygium wilfordii formulation. Pharmagenesis Inc. (US) has been using triptolide as a lead compound since 1995 and has obtained several triptolide derivatives with significant anti-tumor activities and greatly reduced toxicity via successful screening. Among these derivatives, PG490-88 $\mathrm{Na}$ (omtriptolide sodium) has been approved by the US Food and Drug Administration (FDA) and the European Medicines Agency (EMEA). Modification of the chemical structure of triptolide to improve the binding of the active ingredient to target cells is one of the major processes for the development of new anti-tumor chemotherapy drugs [7].

A monolayer HK-2 cell model has been developed in a preliminary study through culture in a transwell chamber, and a complete test system of multiple indicators that cover the morphology and physiological functions of renal tubular epithelial cells has been established. Drug-derived ingredients or extracts with unambiguous renal toxicity were tested using the established monolayer HK-2 cell model. The results showed that these tested ingredients caused different degrees of damage to the HK-2 cell model. The results not only showed an obvious dose-toxicity relationship in multiple tests but also exhibited a strong correlation with the morphological and physiological functional indicators of renal tubules. These findings suggest that this model can be used as a new, rapid and sensitive technical method for early detection of renal tubular toxicity in experimental research, with multi-level and multi-angle endpoints that reflect the renal toxicity of drugs. This study used this monolayer HK-2 cell model to test the effects of tripterygium tablet extract and triptolide on changes in the morphology and physiological functions such as secretion, to determine the intensity of renal injury caused by tripterygium tablet extract and triptolide and their toxic dose. The results can provide a theoretical basis to guide the clinical use of tripterygium glycosides and triptolide and for the development of highly effective tripterygium preparations with low toxicity. 


\section{Materials and Methods}

\subsection{Materials}

Human proximal tubular epithelial cells (HK-2 cells) were purchased from the stem cell bank of the Chinese Academy of Sciences (serial number SCSP-511). Millicell culture plates inserts with standing (polycarbonate membranes with $0.4-\mu \mathrm{m}$ pore size and an effective growth area of $0.6 \mathrm{~cm}^{2}$ ) were obtained from Millipore.

The water used was Watsons purified water produced by A.S. Watson Group Ltd (Hong Kong, CHN). Absolute ethanol was purchased from Beijing Chemical Works, potassium hydroxide was purchased from Sinopharm Chemical Reagent Co. Ltd, and 3,5-dinitrobenzonic acid was purchased from Beijing Kulaibo Science and Technology Ltd. All the reagents were analytical grade.

Reference substance of triptolide was purchased from Beijing Beinachuanglian Academy of Biotechnology ( $\mathrm{CHN})$, and its purity was more than $98 \%$ determined by HPLC.

Dulbecoo's Modified Eagle's Medium (DMEM), Fetal Bovine Serum (FBS) and $0.05 \%$ Trypsin-EDTA were purchased from Gibco (NY), Lot No. were 1750052, 1414426 and 1748048, respectively. Penicillin and streptomycin was purchased from HyClone (UT), Lot No.: J150001. Fluorescein isothiocyanate-dextran (FITC), 4-Aminohippuric acid (PAH), Rhodamine phalloidin and 4',6-diamindino-2-phenylindole were purchased from Sigma (GER), Lot No. were SLBN7796V, 4342861, SLBB7623V and BCBJ0302V, respectively. Lactate Dehydrogenase (LDH), $\gamma$-Glutamyltranspeptidase (GGT) and N-Acetyl- $\beta$-Dglucosaminidas-e (NAG) assay kit were all purchased from Beijing Wantaiderui Diagnostic Technology Co., Ltd. (CHN), Lot No. were XJ6103A, GG6104B, and SG6105A, respectively. Tripterygium tablet was purchased from Anhui Xinlonghai Pharmaceutical Co., Ltd. (CHN).

\subsection{Instruments}

Varioskan Flash Multi-functional microplate reader was provided by the Thermo Electron Corporation (USA). TBA-40 FR Automatic biochemical analyzer was purchased from Toshiba Medical Systems Ltd. (JPN). Olympus BX51 microscope, image analysis system and Olympus IX71 fluorescence microscope were purchased from Olympus company (JPN). S-3400N scanning electron microscope was purchased from Hitachi company (JPN). UV-Vis spectrophotometer was purchased from Beijing General Instrument Co. LTD (CHN). XS105DU analytical balance was purchased from Mettler-Toledo (SUI). KQ-250DB ultrasonic cleaner was purchased from Kunshan ultrasonic instrument co. LTD (CHN).

\subsection{Preparation of Test Substances}

Preparation of Tripterygium tablet extract (TTE): Through the investigation of the extraction solvent and extraction time, reflux extraction of anhydrous ethanol for $1 \mathrm{~h}$ is optimized. 
15 grams of Tripterygium tablet was added to $750 \mathrm{ml}$ of absolute ethanol and reflux extracted for $1 \mathrm{~h}$. The mixture was filtered and the supernatant was vacuum evaporated to dry extract $0.6328 \mathrm{~g}$.

Determination of Tripterygium total lactones in TTE:

Preparation of reference substance solutions: Appropriate amount of triptolide reference substance was precisely weighed and separately put into $10 \mathrm{ml}$ measuring flasks. Then $60 \%$ ethanol was added to the scale, shaking well to make reference substance solutions of $22.6 \mathrm{mg} \cdot \mathrm{l}^{-1}, 81.4 \mathrm{mg} \cdot \mathrm{l}^{-1}, 180.8 \mathrm{mg} \cdot \mathrm{l}^{-1}, 226 \mathrm{mg} \cdot \mathrm{l}^{-1}$ and $407 \mathrm{mg} \cdot \mathrm{l}^{-1}$, respectively, which were used to establish the calibration curve. All the standard solutions were stored at $4^{\circ} \mathrm{C}$ and brought to the room temperature before use.

Preparation of sample solution: About $0.3 \mathrm{~g}$ of TTE was weighed precisely and put into $100 \mathrm{ml}$ conical bottle. Subsequently, $25 \mathrm{ml}$ of $60 \%$ ethanol was added precisely, weighed and reflux extracted by ultrasonic wave $(250 \mathrm{~W}, 40 \mathrm{kHz})$ for 30 minutes, cooling, then making up the weight with $60 \%$ ethanol, shaking well, filtrating and the subsequent filtrate was the test solution.

Linear relationship investigation: $4 \mathrm{ml}$ of triptolide reference substance solutions of different concentrations were precisely measured and separately transferred into $10 \mathrm{ml}$ test tubes, then successively added into $2 \mathrm{ml}$ of 3,5-dinitrobenzoic acid $60 \%$ ethanol solution and $2 \mathrm{ml}$ of $2 \%$ potassium hydroxide $60 \%$ ethanol solution in the ice water bath, mixed well, kept in the ice bath for ten minutes, next immediately removed from the bath and rinsing the test tube wall with tap water for two minutes, mixed well to react. Using $60 \%$ ethanol solution added color development reagents as the reagent blank, measured at $504 \mathrm{~nm}$. Linear regression was conducted with absorption of triptolide under test as ordinate and the mass concentration $\left(\mathrm{mg} \cdot \mathrm{l}^{-1}\right)$ as abscissa. The regression equation was $\mathrm{y}=0.0018 \mathrm{x}$ $+0.0889(\mathrm{r}=0.9995)$. The calibration curve was linear in the range from 22.6 $\mathrm{mg} \cdot \mathrm{l}^{-1} \sim 407 \mathrm{mg} \cdot \mathrm{l}^{-1}$ for the total lactones calculated as triptolide.

Sample assay: $4 \mathrm{ml}$ of sample solution was precisely measured and transferred into a $10 \mathrm{ml}$ test tube, then prepared as the procedure described in the linear relationship investigation. The content of total lactones in TTE was $1.13 \%$ calculate by standard curve.

\subsection{HK-2 Cell Culture}

HK-2 cells were routinely cultured in DMEM medium containing 10\% FBS, 100 $\mathrm{U} \cdot \mathrm{ml}^{-1}$ penicillin, and $100 \mathrm{U} \cdot \mathrm{ml}^{-1}$ streptomycin. The cells were grown maintained in a tissue culture incubator at $37^{\circ} \mathrm{C}$ and $5 \% \mathrm{CO}_{2}$ until $70 \%-80 \%$ confluence and then sub-cultured twice a week. HK-2 cells were seeded in a 96-well plate at a density of $5 \times 10^{4} \mathrm{ml}^{-1}$ or in a 24 -well plate at a density of $2 \times 10^{4} \mathrm{ml}^{-1}$ or in culture plate insert at densities of $3 \times 10^{4} \mathrm{ml}^{-1}$. When seeded in culture plate insert, the cell growth support was $0.4-\mu \mathrm{m}$ polycarbonate membranes (PCF membranes), and $400 \mu \mathrm{l}$ and $600 \mu \mathrm{l}$ of serum-containing medium were added, respectively, to the chamber inside and outside. 


\subsection{Effect on HK-2 Cell Proliferation}

HK-2 cells were seeded in a 96-well plate at a density of $5 \times 10^{4} \mathrm{ml}^{-1}, 100 \mu \mathrm{l} /$ well, at $37^{\circ} \mathrm{C}$ and $5 \% \mathrm{CO}_{2}$, and test substances were added after 24 hours of culture. TTE and triptolide were solubilized with dimethyl sulfoxide (DMSO); the final concentrations of TTE were 2000, 1000, 500, 250, 125, 62.5, 31.25, 15.625, 7.8125 and $3.90625 \mu \mathrm{g} \cdot \mathrm{ml}^{-1}$, and the final concentrations of triptolide were 2000, 1000, $500,250,125,62.5,31.25,15.625,7.8125$ and $3.90625 \mathrm{ng} \cdot \mathrm{ml}^{-1}$; the final concentration of DMSO was $0.5 \%$. A medium control group and a $0.5 \%$ DMSO control group were included. After treatment with the test substances for 24 hours, the supernatant was discarded, and $100 \mu \mathrm{l}$ of $1 \mathrm{mg} \cdot \mathrm{ml}^{-1}$ MTT solution was added to each well. After incubation at $37^{\circ} \mathrm{C}$ for 4 hours, the supernatant was discarded, and $200 \mu \mathrm{l}$ of DMSO was added to each well. The absorbance (A) was measured at $570 \mathrm{~nm}$. The inhibition rate of HK-2 cell (\%) and half-maximal inhibitory concentration $\left(\mathrm{IC}_{50}\right)$ were calculated. The concentration at which the tested drug exhibited no inhibition or significant inhibition was selected for the following toxicity test.

\subsection{Effect on the FITC Permeability of Monolayer HK-2 Cells}

HK-2 cells were seeded in a culture plate insert at a density of $3 \times 10^{4} / \mathrm{ml}$, and $400 \mu \mathrm{l}$ and $600 \mu \mathrm{l}$ of serum-containing culture medium were added to the inside and outside of the insert, respectively, followed by culture at $37^{\circ} \mathrm{C}$ and $5 \% \mathrm{CO}_{2}$ and addition of the test substances after 3 days. The final concentrations of TTE were $10,40,160$, and $640 \mu \mathrm{g} \cdot \mathrm{ml}^{-1}$ and triptolide were $4,16,64$ and $256 \mathrm{ng} \cdot \mathrm{ml}^{-1}$ (TTE and triptolide were solubilized with DMSO, the final concentration of DMSO was $0.5 \%)$. After cells were treated with the test substances for 24 hours, the drug solution was aspirated from both sides of the cells, and the cells were gently rinsed twice, followed by addition of $400 \mu \mathrm{L}$ of $1 \mathrm{mg} \cdot \mathrm{ml}^{-1}$ FITC solution to the apical (AP) side and $600 \mu \mathrm{L}$ of culture medium to the basolateral (BL) side. The liquid on the BL side was aspirated and replaced with $600 \mu \mathrm{L}$ of fresh culture medium once every 15 minutes. The blank control was a transwell chamber with no cells, which underwent the same procedure, and samples were collected once every 15 minutes. The fluorescence intensity of the samples from the cells cultured at different densities for different duration was measured at the excitation wavelength of $485 \mathrm{~nm}$ and the emission wavelength of $510 \mathrm{~nm}$. A standard curve was generated with a set of different FITC concentrations, and the amount of leaked FITC was calculated for each transwell chamber, which was compared with the blank control group with no cells to calculate the percentage of cumulative leakage of FITC within 2 hours.

\subsection{Effect on the Secretion of GGT, LDH, and NAG on Both Sides of HK-2 Cells}

HK-2 cells were plated, cultured and treated with the test substances using the method as above. Culture medium was aspirated from both side of the cells, and 
the LDH, GGT, and NAG activities were measured using an automated biochemistry analyzer. The results were expressed as $\mathrm{U} \cdot \mathrm{L}^{-1}$.

\subsection{Effect on the Morphology of HK-2 Monolayer Cells}

HK-2 cells were plated, cultured and treated with the test substances using the method as above. The monolayer HK-2 cells on the transwell chamber were fixed with $2.5 \%$ glutaraldehyde for 24 hours, and then, each PCF membrane with cells was carefully cut off and placed on a slide with the cell-containing side of the membrane facing the slide. The slide was then immersed in chloroform for 15 minutes to dissolve the membrane, which was followed by standard Hematoxylin-Eosin staining ( $\mathrm{H} \& \mathrm{E}$ ) and pathology grading was performed according to the grading criteria of pathological changes outlined in Table 1 . The samples of the monolayer HK-2 were subjected to gradient dehydration and freeze-drying and then fixed on the sample platform with double-sided conductive adhesive and sprayed with gold coating. Finally, they were examined with a scanning electron microscope (SEM) to observe the cell morphology.

\subsection{Effect on F-Actin Expression in Monolayer HK-2 Cells}

HK- 2 cells were seeded in a 24 -well plate at a density of $2 \times 10^{4} / \mathrm{ml}, 1 \mathrm{ml} /$ well, at $37^{\circ} \mathrm{C}$ and $5 \% \mathrm{CO}_{2}$, and the test substances were added after 24 hours of culture. The final concentrations of TTE were 10, 40, 160, and $640 \mu \mathrm{g} \cdot \mathrm{ml}^{-1}$ and triptolide were 4, 16, 64 and $256 \mathrm{ng} \cdot \mathrm{ml}^{-1}$ (TTE and triptolide were solubilized with DMSO, the final concentration of DMSO was $0.5 \%$ ). A medium control group and a $0.5 \%$ DMSO control group were included. After cells were treated with the test substances for 24 hours, the supernatant was discarded, and the cells were washed with pre-warmed saline, followed by fixation with $4 \%$ paraformaldehyde for 10 minutes, $200 \mu \mathrm{l} /$ well. The cells were then washed 3 times, for 3 minutes each time, followed by blocking with 1\% BSA for 1 hour and fluorescence staining of the cells with rhodamine-phalloidin working solution $(5 \mu \mathrm{g} / \mathrm{ml})$ for 60 minutes, with $90 \mu \mathrm{l}$ in each well. The cells were then washed 5 times, for $5 \mathrm{mi}-$ nutes each time, followed by nuclear staining with 4',6-diamidino-2-phenylindole

Table 1. The standard of HK-2 cell pathological grading.

\begin{tabular}{cl}
\hline $\begin{array}{c}\text { Pathological } \\
\text { grading }\end{array}$ & \multicolumn{1}{c}{ Description of pathological changes } \\
\hline & $\begin{array}{l}\text { HK-2 cells were uniform in shape and size, and no obvious pathological change was } \\
\text { found. }\end{array}$ \\
& $\begin{array}{l}\text { Individual cell degeneration, karyopyknosis and hyperchromatic were observed, the } \\
\text { proportion of cytoplasm and nucleus was abnormal. }\end{array}$ \\
& $\begin{array}{l}\text { Focal or small flakes cell degeneration, karyopyknosis and hyperchromatic were } \\
\text { observed, the proportion of cytoplasm and nucleus was abnormal. }\end{array}$ \\
& $\begin{array}{l}\text { Large area diffuse cell degeneration, karyopyknosis and hyperchromatic were } \\
\text { observed, the proportion of cytoplasm and nucleus was abnormal, loose } \\
\text { arrangement between cells was found. }\end{array}$ \\
\hline
\end{tabular}


(DAPI) for 5 minutes. The cells were then washed 5 times, for 5 minutes each time, followed by observation of F-actin expression under an inverted fluorescence microscope.

\section{Statistics}

The data from the measurement of absorbance (A), fluorescence, activity were expressed as $\bar{X} \pm \mathrm{S}$ and analyzed with Student's t test implemented in the SPSS statistical software. Pathological scores were analyzed with Kruskal-Wallis $\mathrm{H}$ test. Differences were considered significant when $P<0.05$ in the comparison between the control, DMSO and blank control groups and the comparison between the drug treatment group and DMSO group.

The following formulas were used to calculate cell inhibition rate (\%), cumulative FITC leakage rate (\%), $\mathrm{AP} / \mathrm{BL}$ ratio, and total content on both sides of the cells $(\mathrm{AP}+\mathrm{BL})$.

Cell inhibition rate $(\%)=(\mathrm{A}$ of the DMSO control well $-\mathrm{A}$ of the drug-treated well)/A of the DMSO control well $\times 100$

Percentage of cumulative FITC leakage $(\%)=$ the sum of the amount of FITC that crossed the membrane during a certain time period in a group/the sum of the amount of FITC that crossed the membrane during the same time period in the blank control group $\times 100$

$\mathrm{AP} / \mathrm{BL}=$ activity on the $\mathrm{AP}$ side/activity on the $\mathrm{BL}$ side

$\mathrm{AP}+\mathrm{BL}=($ activity on the AP side $\times 0.4)+($ activity on the BL side $\times 0.6) /(0.4+$ $0.6)$

\section{Results}

\subsection{Effect on HK-2 Cell Proliferation}

The MTT assay results indicated that TTE exhibited no significant inhibition of HK-2 cell growth at $31.25 \mu \mathrm{g} \cdot \mathrm{ml}^{-1}$ and below but caused significant inhibition of HK-2 cell growth at concentrations above $31.25 \mu \mathrm{g} \cdot \mathrm{ml}^{-1}$; its $\mathrm{IC}_{50}$ was 277.122 $\mu \mathrm{g} \cdot \mathrm{ml}^{-1}$. Triptolide exhibited no significant inhibition of HK-2 cell growth at $3.90625 \mathrm{ng} \cdot \mathrm{ml}^{-1}$ but exhibited significant inhibition of $\mathrm{HK}-2$ cell growth at $7.8125 \mathrm{ng} \cdot \mathrm{ml}^{-1}$ and above; its $\mathrm{IC}_{50}$ was $148.035 \mathrm{ng} \cdot \mathrm{ml}^{-1}$. The results are summarized in Table 2 and Figure 1 \& Figure 2.

\subsection{Effect on the Cumulative FITC Leakage Rate of Monolayer HK-2 Cells}

The results indicated that the permeability rate of the 10 and $40 \mu \mathrm{g} \cdot \mathrm{ml}^{-1} \mathrm{TTE}$ group were similar to that of $0.5 \%$ DMSO control group at each time, and the 2-hour permeability rate was $3.37 \%$ and $4.09 \%$, respectively; cells treated with $160 \mu \mathrm{g} \cdot \mathrm{ml}^{-1} \mathrm{TTE}$ at $45-120 \mathrm{~min}$ and with $640 \mu \mathrm{g} \cdot \mathrm{ml}^{-1} \mathrm{TTE}$ at $15-120 \mathrm{~min}$ exhibited significantly greater cumulative permeability rates than those in the DMSO control group $(P<0.05, P<0.01, P<0.001)$, the 2 -hour FITC permeability rate was $16.08 \%$ and $68.67 \%$, respectively, thus indicating a certain degree of 
Table 2. The effect of TTE and triptolide on the cell proliferation $(\bar{x} \pm S, n=6)$.

\begin{tabular}{|c|c|c|c|}
\hline group & dose $/ \mu \mathrm{g} \cdot \mathrm{ml}^{-1}$ & A & inhibition ratio/\% \\
\hline medium control & - & $0.971 \pm 0.062$ & - \\
\hline DMSO control & - & $0.737 \pm 0.041$ & - \\
\hline \multirow[t]{10}{*}{ TTE } & $3.90625 \mu \mathrm{g} \cdot \mathrm{ml}^{-1}$ & $0.744 \pm 0.050$ & -0.962 \\
\hline & $7.8125 \mu \mathrm{g} \cdot \mathrm{ml}^{-1}$ & $0.707 \pm 0.058$ & 4.080 \\
\hline & $15.625 \mu \mathrm{g} \cdot \mathrm{ml}^{-1}$ & $0.727 \pm 0.079$ & 1.381 \\
\hline & $31.25 \mu \mathrm{g} \cdot \mathrm{ml}^{-1}$ & $0.657 \pm 0.075$ & 10.894 \\
\hline & $62.5 \mu \mathrm{g} \cdot \mathrm{ml}^{-1}$ & $0.601 \pm 0.104^{*}$ & 18.436 \\
\hline & $125 \mu \mathrm{g} \cdot \mathrm{ml}^{-1}$ & $0.359 \pm 0.041^{\star * *}$ & 51.373 \\
\hline & $250 \mu \mathrm{g} \cdot \mathrm{ml}^{-1}$ & $0.328 \pm 0.037^{\star * *}$ & 55.478 \\
\hline & $500 \mu \mathrm{g} \cdot \mathrm{ml}^{-1}$ & $0.281 \pm 0.027^{\star * \star}$ & 61.846 \\
\hline & $1000 \mu \mathrm{g} \cdot \mathrm{ml}^{-1}$ & $0.277 \pm 0.025^{\star * \star}$ & 62.375 \\
\hline & $2000 \mu \mathrm{g} \cdot \mathrm{ml}^{-1}$ & $0.110 \pm 0.003^{\star * *}$ & 85.128 \\
\hline medium control & - & $1.771 \pm 0.160$ & - \\
\hline DMSO control & - & $1.727 \pm 0.094$ & - \\
\hline \multirow[t]{10}{*}{ triptolide } & $3.90625 \mathrm{ng} \cdot \mathrm{ml}^{-1}$ & $1.743 \pm 0.069$ & -0.897 \\
\hline & $7.8125 \mathrm{ng} \cdot \mathrm{ml}^{-1}$ & $1.511 \pm 0.125^{\star *}$ & 12.508 \\
\hline & $15.625 \mathrm{ng} \cdot \mathrm{ml}^{-1}$ & $1.388 \pm 0.139^{\star * *}$ & 19.639 \\
\hline & $31.25 \mathrm{ng} \cdot \mathrm{ml}^{-1}$ & $1.002 \pm 0.142^{\star * *}$ & 42.011 \\
\hline & $62.5 \mathrm{ng} \cdot \mathrm{ml}^{-1}$ & $0.997 \pm 0.106^{* * *}$ & 42.282 \\
\hline & $125 \mathrm{ng} \cdot \mathrm{ml}^{-1}$ & $0.736 \pm 0.040^{\star * *}$ & 57.407 \\
\hline & $250 \mathrm{ng} \cdot \mathrm{ml}^{-1}$ & $0.584 \pm 0.030^{\star * *}$ & 66.214 \\
\hline & $500 \mathrm{ng} \cdot \mathrm{ml}^{-1}$ & $0.572 \pm 0.058^{\star * *}$ & 66.861 \\
\hline & $1000 \mathrm{ng} \cdot \mathrm{ml}^{-1}$ & $0.615 \pm 0.056^{\star * *}$ & 64.375 \\
\hline & $2000 \mathrm{ng} \cdot \mathrm{ml}^{-1}$ & $0.592 \pm 0.063^{* * *}$ & 65.705 \\
\hline
\end{tabular}

Note: Compared with DMSO control group, ${ }^{*} P<0.05,{ }^{*} P<0.01,{ }^{* *} P<0.001$.

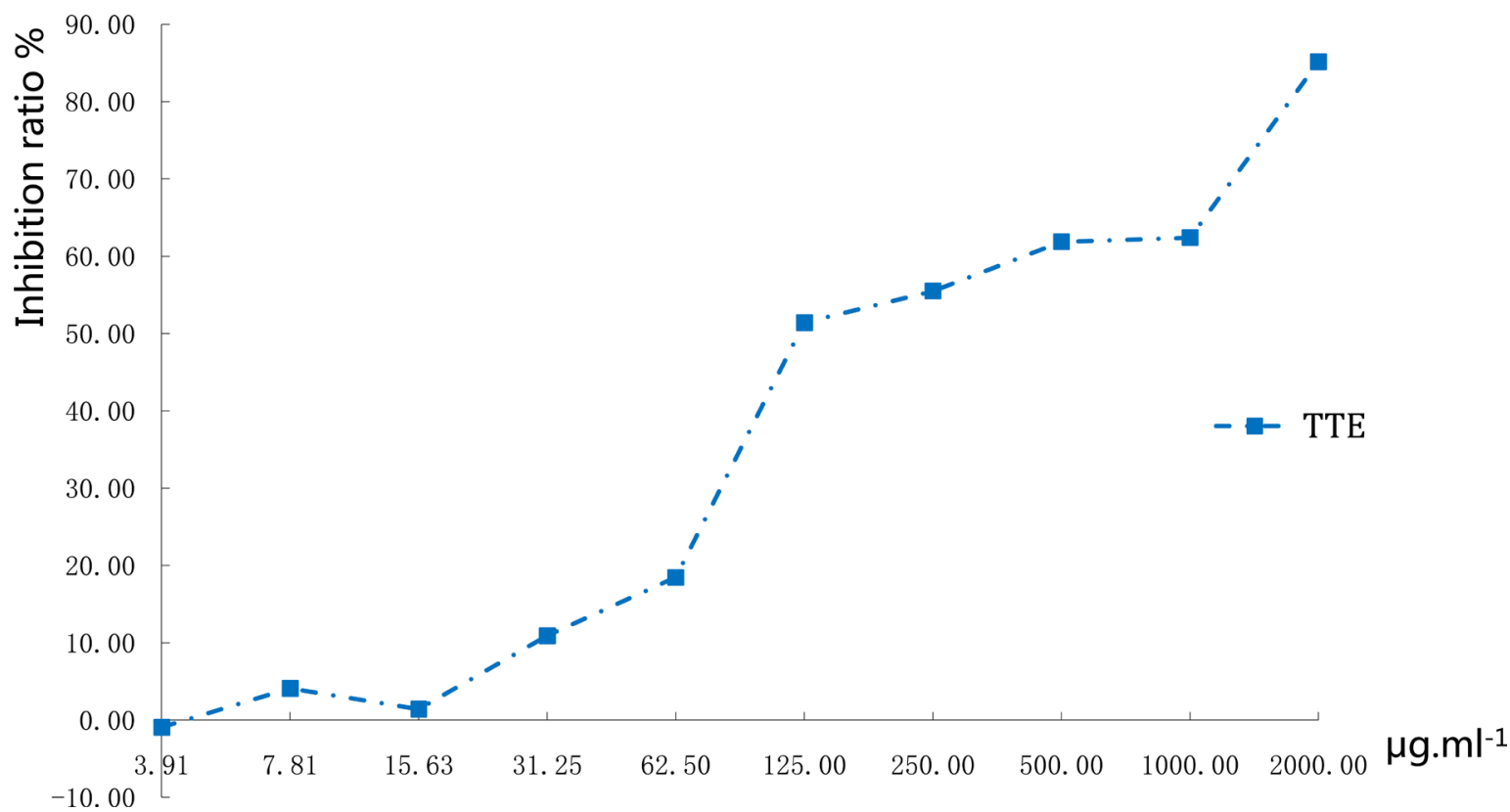

Figure 1. The effect of TTE on the HK-2 cell proliferation. 


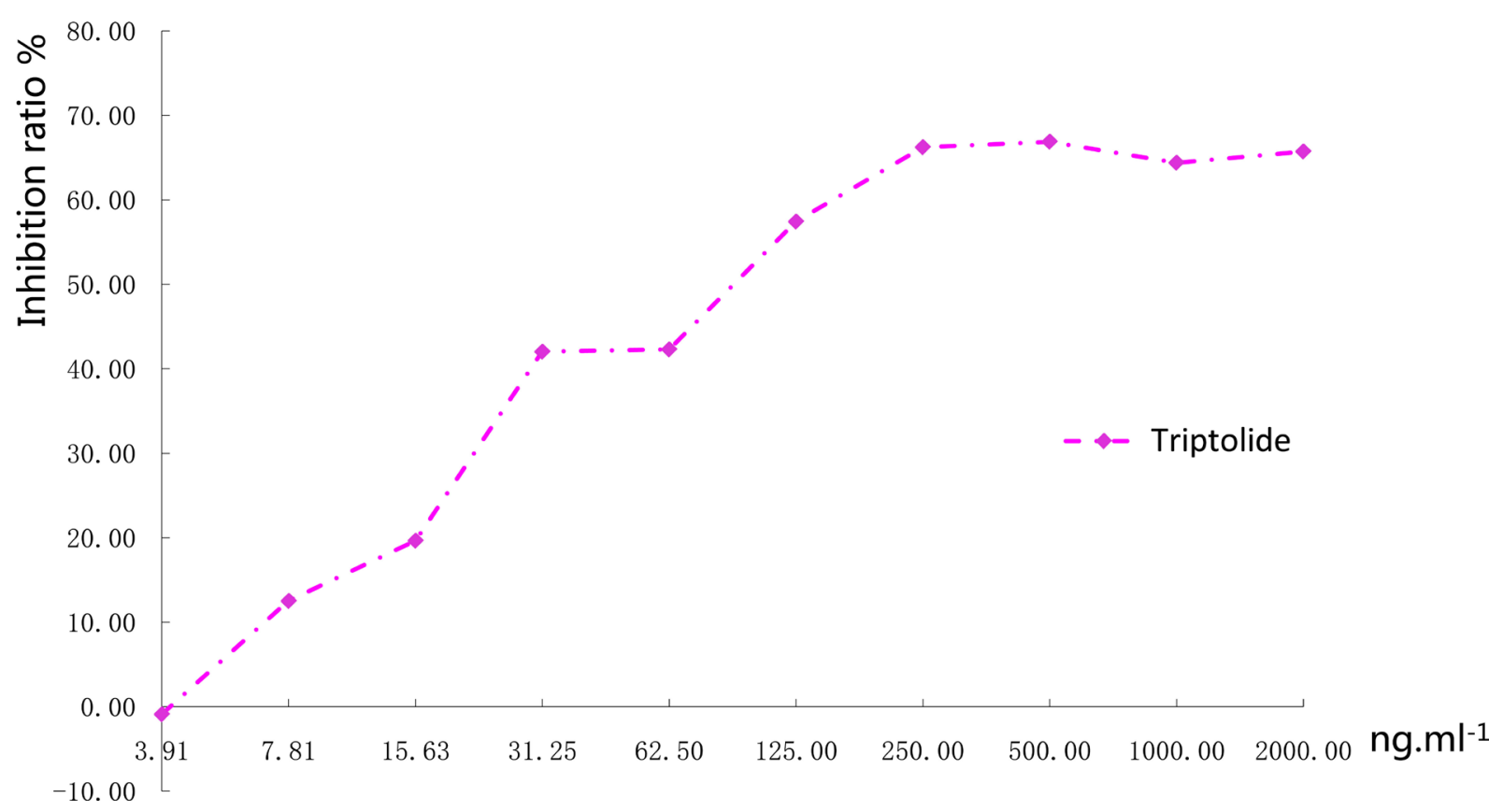

Figure 2. The effect of triptolide on the HK-2 cell proliferation.

Table 3. The effect of TTE and triptolide on the percentage of cumulative FITC leakage of HK-2 cell $(\bar{x} \pm \mathrm{S}, \mathrm{n}=3)$.

\begin{tabular}{|c|c|c|c|c|c|c|c|c|c|}
\hline \multirow{2}{*}{ group } & \multirow{2}{*}{ dose } & \multicolumn{8}{|c|}{ percentage of cumulative FITC leakage/\% } \\
\hline & & $15 \mathrm{~min}$ & $30 \mathrm{~min}$ & $45 \mathrm{~min}$ & $60 \mathrm{~min}$ & $75 \mathrm{~min}$ & $90 \mathrm{~min}$ & $105 \mathrm{~min}$ & $120 \mathrm{~min}$ \\
\hline medium control & - & $1.74 \pm 0.38$ & $2.10 \pm 0.45$ & $2.59 \pm 0.59$ & $3.22 \pm 0.69$ & $3.51 \pm 0.65$ & $3.94 \pm 0.79$ & $4.14 \pm 0.79$ & $4.42 \pm 0.81$ \\
\hline DMSO control & - & $1.74 \pm 0.61$ & $2.07 \pm 0.77$ & $2.49 \pm 0.90$ & $3.07 \pm 1.04$ & $3.36 \pm 1.08$ & $3.79 \pm 1.15$ & $3.91 \pm 1.09$ & $4.19 \pm 1.14$ \\
\hline \multirow[t]{3}{*}{ TTE } & $10 \mu \mathrm{g} \cdot \mathrm{ml}^{-1}$ & $1.45 \pm 0.28$ & $1.73 \pm 0.41$ & $2.04 \pm 0.50$ & $2.41 \pm 0.51$ & $2.66 \pm 0.51$ & $3.02 \pm 0.59$ & $3.15 \pm 0.55$ & $3.37 \pm 0.54$ \\
\hline & $160 \mu \mathrm{g} \cdot \mathrm{ml}^{-1}$ & $8.08 \pm 3.30$ & $10.40 \pm 4.16$ & $11.74 \pm 3.89^{*}$ & $13.34 \pm 4.05^{*}$ & $14.05 \pm 3.91^{*}$ & $15.51 \pm 4.44^{*}$ & $15.56 \pm 4.44^{*}$ & $16.08 \pm 4.45^{\star}$ \\
\hline & $640 \mu \mathrm{g} \cdot \mathrm{ml}^{-1}$ & $40.23 \pm 4.95^{\star *}$ & $51.85 \pm 3.17^{* * *}$ & $59.36 \pm 2.39^{* * *}$ & $63.73 \pm 2.61^{* * *}$ & $65.55 \pm 2.04^{* * *}$ & $70.74 \pm 4.64^{\star * *}$ & $68.31 \pm 4.49^{\star * *}$ & $68.67 \pm 4.41^{* * *}$ \\
\hline medium control & - & $1.44 \pm 0.09$ & $1.97 \pm 0.14$ & $2.23 \pm 0.13$ & $2.47 \pm 0.08$ & $2.87 \pm 0.07$ & $3.32 \pm 0.07$ & $3.64 \pm 0.06$ & $3.88 \pm 0.04$ \\
\hline DMSO control & - & $1.77 \pm 0.24$ & $2.67 \pm 0.31$ & $3.03 \pm 0.34$ & $3.11 \pm 0.31$ & $3.34 \pm 0.27$ & $3.55 \pm 0.25$ & $3.77 \pm 0.24$ & $3.92 \pm 0.22$ \\
\hline \multirow{3}{*}{ triptolide } & $16 \mathrm{ng} \cdot \mathrm{ml}^{-1}$ & $3.07 \pm 0.34^{\star *}$ & $4.34 \pm 0.41^{* *}$ & $4.62 \pm 0.41^{\star \star}$ & $4.67 \pm 0.40^{\star *}$ & $4.90 \pm 0.40^{* *}$ & $5.07 \pm 0.37^{\star *}$ & $5.26 \pm 0.36^{* *}$ & $5.38 \pm 0.34^{* *}$ \\
\hline & $64 \mathrm{ng} \cdot \mathrm{ml}^{-1}$ & $2.41 \pm 0.12^{\star}$ & $3.43 \pm 0.15^{\star}$ & $3.72 \pm 0.17^{\star}$ & $3.76 \pm 0.15^{\star}$ & $3.99 \pm 0.17^{\star}$ & $4.18 \pm 0.18^{*}$ & $4.40 \pm 0.19^{*}$ & $4.52 \pm 0.19^{\star}$ \\
\hline & $256 \mathrm{ng} \cdot \mathrm{ml}^{-1}$ & $5.75 \pm 0.64^{* *}$ & $8.07 \pm 0.70^{\star *}$ & $9.32 \pm 0.80^{* *}$ & $9.53 \pm 0.89^{\star *}$ & $10.19 \pm 1.03^{* *}$ & $10.75 \pm 1.03^{* *}$ & $11.37 \pm 1.02^{* *}$ & $11.88 \pm 1.07^{\star *}$ \\
\hline
\end{tabular}

Note: Compared with DMSO control group, ${ }^{*} P<0.05,{ }^{* *} P<0.01,{ }^{* * *} P<0.001$ (the same as Figure 3 and Figure 4).

dose-dependent toxicity. Cells treated with triptolide at 4-256 $\mu \mathrm{g} \cdot \mathrm{ml}^{-1}$ exhibited cumulative permeability rates that were significantly greater than the cells of the DMSO control group at each time $(P<0.05, P<0.01)$, and the 2-hour FITC permeability rate was $5.62 \%, 5.38 \%, 4.52 \%$ and $11.88 \%$, respectively. The above results suggest that TTE at concentrations of greater than $40 \mu \mathrm{g} \cdot \mathrm{ml}^{-1}$ and triptolide at concentrations of $4 \mathrm{ng} \cdot \mathrm{ml}^{-1}$ and above caused different degrees of damage to the integrity of the cell monolayers. The results are summarized in Table 3 and Figure 3 \& Figure 4. 


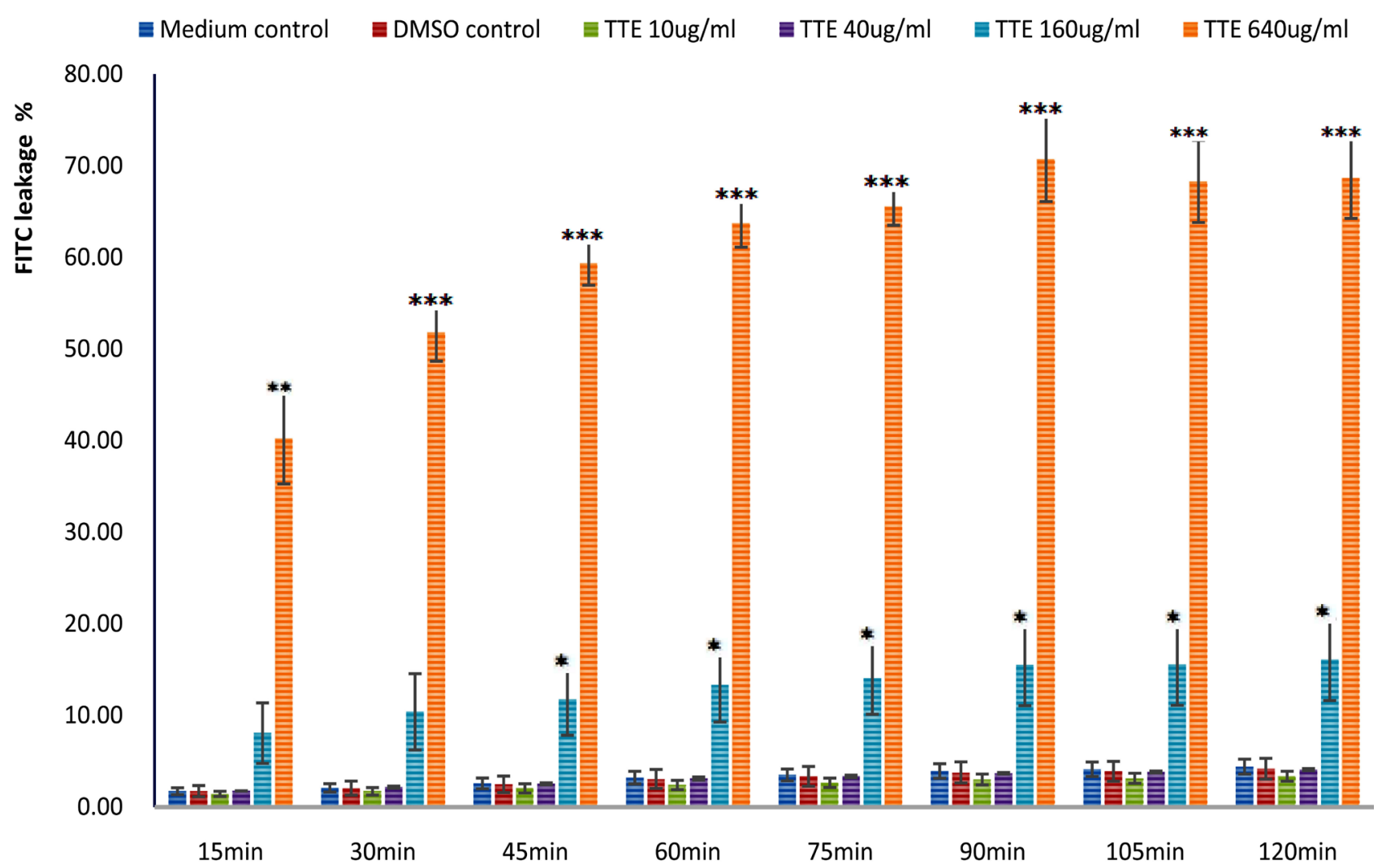

Figure 3. The effect of TTE on the percentage of cumulative FITC leakage of HK-2 cell.

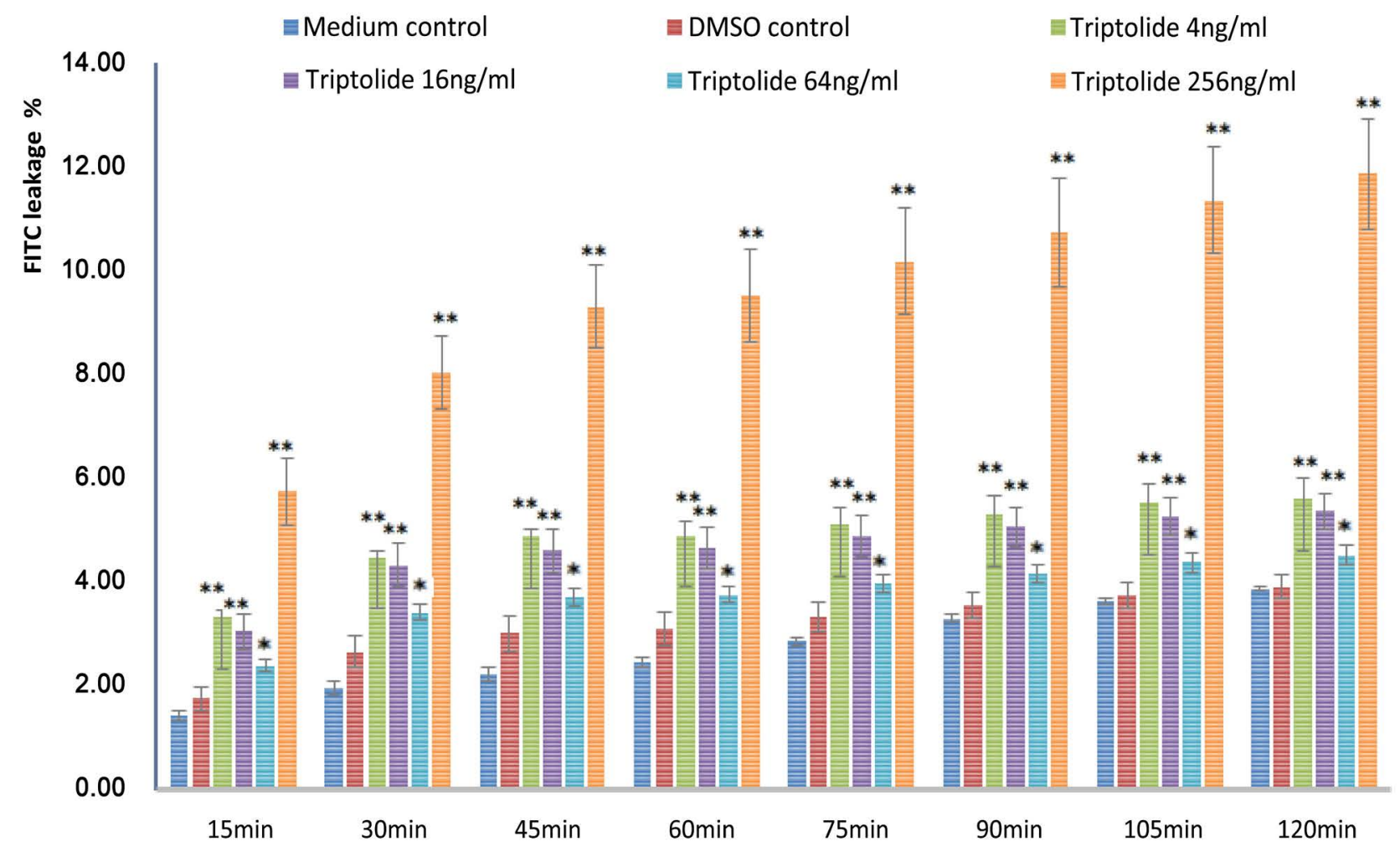

Figure 4. The effect of triptolide on the percentage of cumulative FITC leakage of HK-2 cell. 


\subsection{Effect on the Secretion of GGT, LDH, and NAG on Both Sides of HK-2 Cells}

The GGT and LDH secretion in the normal HK-2 cells exhibited obvious polarity, which was mainly on the luminal side of the cells. Thus, the levels of GGT and $\mathrm{LDH}$ on the AP side were greater than those on the BL side, representing a significant difference from the blank control group with no cells $(P<0.05, P<$ 0.01 ); no significant polarity was observed on the NAG secretion in the normal HK-2 cells. After incubation with HK-2 cells for 24 hours, TTE caused a dosedependent increase in the total GGT and LDH activity; TTE induced significantly elevated GGT and LDH levels at 160 and $640 \mu \mathrm{g} \cdot \mathrm{ml}^{-1}(P<0.05, P<0.01, P$ $<0.001)$ but did not have any effect on NAG. Triptolide raised GGT, LDH and NAG levels at $256 \mathrm{ng} \cdot \mathrm{ml}^{-1}(P<0.05, P<0.01)$. TTE remarkably increased the $\mathrm{AP} / \mathrm{BL}$ ratio of GGT and $\mathrm{LDH}$ at $160 \mu \mathrm{g} \cdot \mathrm{ml}^{-1}$, with a significant difference in that of LDH compared with the DMSO group $(P<0.05)$; with increasing dose of TTE, at $640 \mu \mathrm{g} \cdot \mathrm{ml}^{-1} \mathrm{TTE}$, the $\mathrm{AP} / \mathrm{BL}$ ratios decreased, it might be relate to serious damage to the integrity of the cells (the FITC leakage rate was $68.67 \%$ at this dose). Triptolide caused an increase in the AP/BL ratio of GGT, LDH and $\mathrm{NAG}$ at $256 \mathrm{ng} \cdot \mathrm{ml}^{-1}$. These findings suggest that TTE at concentrations of 160 $\mu \mathrm{g} \cdot \mathrm{ml}^{-1}$ and above and triptolide at concentrations of $256 \mathrm{ng} \cdot \mathrm{ml}^{-1}$, could affect secretion of HK-2 cell, leading to changes in the AP/BL ratios or the total secretion amounts. The results are summarized in Table 4 and Figures 5-7.

Table 4. The effect of TTE and triptolide on the activity of GGT, LDH and NAG $(\bar{x} \pm \mathrm{S}, \mathrm{n}=3)$.

\begin{tabular}{|c|c|c|c|c|c|c|c|}
\hline \multirow{2}{*}{ group } & \multirow{2}{*}{ dose } & \multicolumn{2}{|c|}{ GGT(U/L) } & \multicolumn{2}{|c|}{$\mathrm{LDH}(\mathrm{U} / \mathrm{L})$} & \multicolumn{2}{|c|}{ NAG(U/L) } \\
\hline & & $\mathrm{AP} / \mathrm{BL}$ & $\mathrm{AP}+\mathrm{BL}$ & $\mathrm{AP} / \mathrm{BL}$ & $\mathrm{AP}+\mathrm{BL}$ & $\mathrm{AP} / \mathrm{BL}$ & $\mathrm{AP}+\mathrm{BL}$ \\
\hline blank control & - & $0.62 \pm 0.46$ & $0.60 \pm 0.24$ & $0.00 \pm 0.00$ & $-4.39 \pm 0.75$ & $0.84 \pm 0.09$ & $9.97 \pm 0.93$ \\
\hline medium control & - & $1.55 \pm 0.29^{\#}$ & $1.11 \pm 0.10^{\#}$ & $4.47 \pm 0.47^{\# \#}$ & $9.56 \pm 1.00^{\# \# \#}$ & $1.02 \pm 0.06$ & $10.45 \pm 0.27$ \\
\hline DMSO control & - & $1.70 \pm 0.89$ & $1.09 \pm 0.13^{\#}$ & $6.12 \pm 3.95$ & $13.62 \pm 3.41^{\# \#}$ & $1.09 \pm 0.09$ & $11.00 \pm 1.26$ \\
\hline \multirow[t]{4}{*}{ TTE } & $10 \mu \mathrm{g} \cdot \mathrm{ml}^{-1}$ & $3.91 \pm 0.50$ & $0.65 \pm 0.14$ & $22.71 \pm 25.62$ & $7.67 \pm 2.45$ & $1.07 \pm 0.07$ & $10.61 \pm 1.18$ \\
\hline & $40 \mu \mathrm{g} \cdot \mathrm{ml}^{-1}$ & $3.60 \pm 2.10$ & $1.11 \pm 0.18$ & $9.66 \pm 3.47$ & $9.38 \pm 3.05$ & $1.13 \pm 0.05$ & $11.01 \pm 1.62$ \\
\hline & $160 \mu \mathrm{g} \cdot \mathrm{ml}^{-1}$ & $5.65 \pm 3.98$ & $1.90 \pm 0.10^{*}$ & $18.70 \pm 4.25^{\star}$ & $27.33 \pm 5.99^{\star}$ & $1.19 \pm 0.09$ & $10.82 \pm 1.33$ \\
\hline & $640 \mu \mathrm{g} \cdot \mathrm{ml}^{-1}$ & $3.76 \pm 0.22$ & $2.89 \pm 0.38^{* *}$ & $4.95 \pm 0.80$ & $62.20 \pm 3.43^{* * *}$ & $1.24 \pm 0.21$ & $11.05 \pm 1.12$ \\
\hline blank control & - & $0.61 \pm 0.62$ & $0.16 \pm 0.10$ & $0.00 \pm 0.00$ & $-0.70 \pm 0.78$ & $1.02 \pm 0.02$ & $10.13 \pm 0.32$ \\
\hline medium control & - & $1.84 \pm 0.25$ & $1.16 \pm 0.19^{\# \#}$ & $3.00 \pm 0.48^{\# \#}$ & $24.63 \pm 3.01^{\# \#}$ & $1.03 \pm 0.05$ & $12.31 \pm 1.17$ \\
\hline DMSO control & - & $1.94 \pm 0.55$ & $1.22 \pm 0.12^{\# \# \#}$ & $4.16 \pm 1.63^{\#}$ & $31.23 \pm 7.33^{\#}$ & $0.95 \pm 0.08$ & $12.81 \pm 1.90$ \\
\hline \multirow[t]{4}{*}{ triptolide } & $4 \mathrm{ng} \cdot \mathrm{ml}^{-1}$ & $1.80 \pm 0.29$ & $1.11 \pm 0.15$ & $1.92 \pm 0.44$ & $33.07 \pm 5.94$ & $0.93 \pm 0.11$ & $12.87 \pm 1.70$ \\
\hline & $16 \mathrm{ng} \cdot \mathrm{ml}^{-1}$ & $1.66 \pm 0.86$ & $1.20 \pm 0.15$ & $2.24 \pm 0.37$ & $36.66 \pm 1.23$ & $0.96 \pm 0.11$ & $12.96 \pm 2.01$ \\
\hline & $64 \mathrm{ng} \cdot \mathrm{ml}^{-1}$ & $1.40 \pm 0.31$ & $1.30 \pm 0.12$ & $3.17 \pm 0.34$ & $44.30 \pm 6.90$ & $1.12 \pm 0.11$ & $13.26 \pm 1.87$ \\
\hline & $256 \mathrm{ng} \cdot \mathrm{ml}^{-1}$ & $4.22 \pm 0.62^{\star *}$ & $2.48 \pm 0.35^{*}$ & $8.67 \pm 1.53^{*}$ & $126.58 \pm 14.71^{\star *}$ & $1.50 \pm 0.07^{*}$ & $17.14 \pm 0.42^{\star}$ \\
\hline
\end{tabular}

Note: 1) Compared with blank control group, ${ }^{*} P<0.05,{ }^{* * *} P<0.01$ (the same as Figures 5-7). 2) Compared with DMSO control group, ${ }^{*} P<0.05,{ }^{* *} P<$ $0.01,{ }^{* * *} P<0.001$ (the same as Figures 5-7). 3) Gamma-glutamyl transpeptidase (GGT), lactate dehydrogenase (LDH) and $\beta$-N-acetyl-glucosaminidase (NAG). 


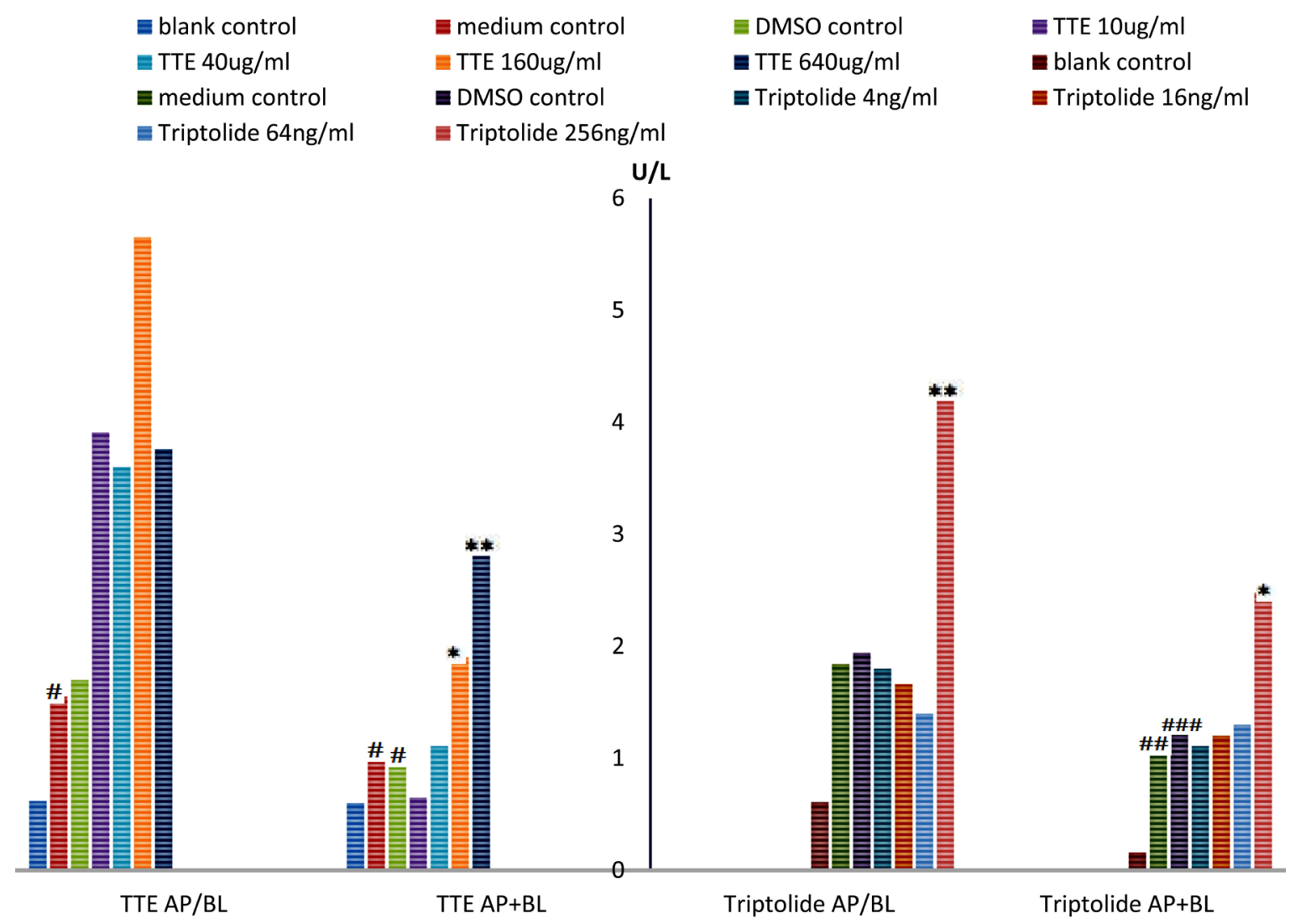

Figure 5. The effect of TTE and triptolide on the activity of GGT.

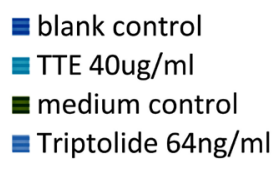

E blank control

E medium control

E Triptolide $64 \mathrm{ng} / \mathrm{ml}$

$$
\begin{aligned}
& \text { E medium control } \\
& \text { ETTE } 160 \mathrm{ug} / \mathrm{ml} \\
& \text { E DMSO control } \\
& \text { ETriptolide } 256 \mathrm{ng} / \mathrm{ml}
\end{aligned}
$$

E DMSO control

ETTE 640ug/ml

E Triptolide $4 \mathrm{ng} / \mathrm{ml}$
E TTE $10 \mathrm{ug} / \mathrm{ml}$

E blank control

E Triptolide $16 \mathrm{ng} / \mathrm{ml}$

$\mathrm{U} / \mathrm{L}$

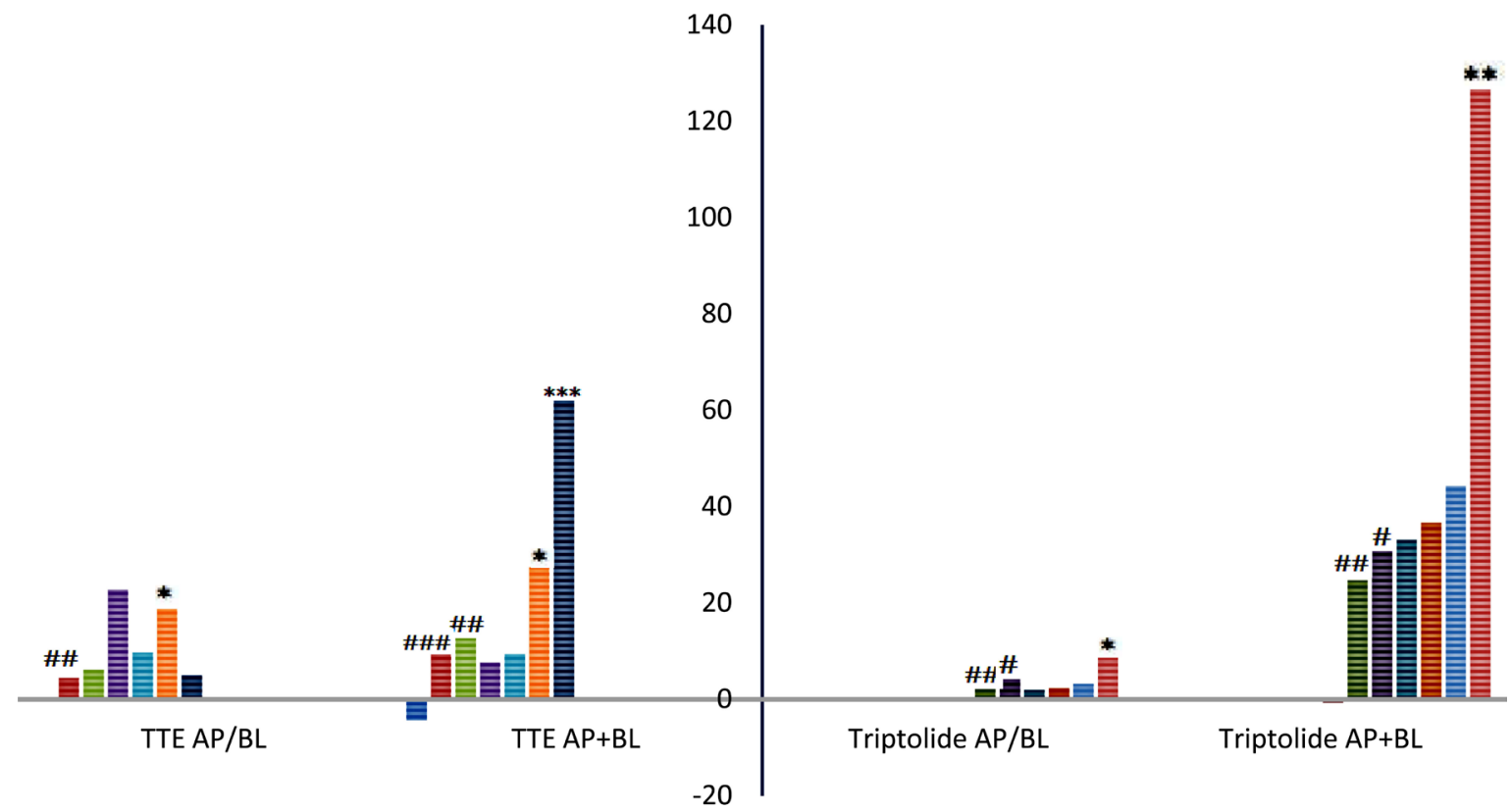

Figure 6. The effect of TTE and triptolide on the activity of LDH. 


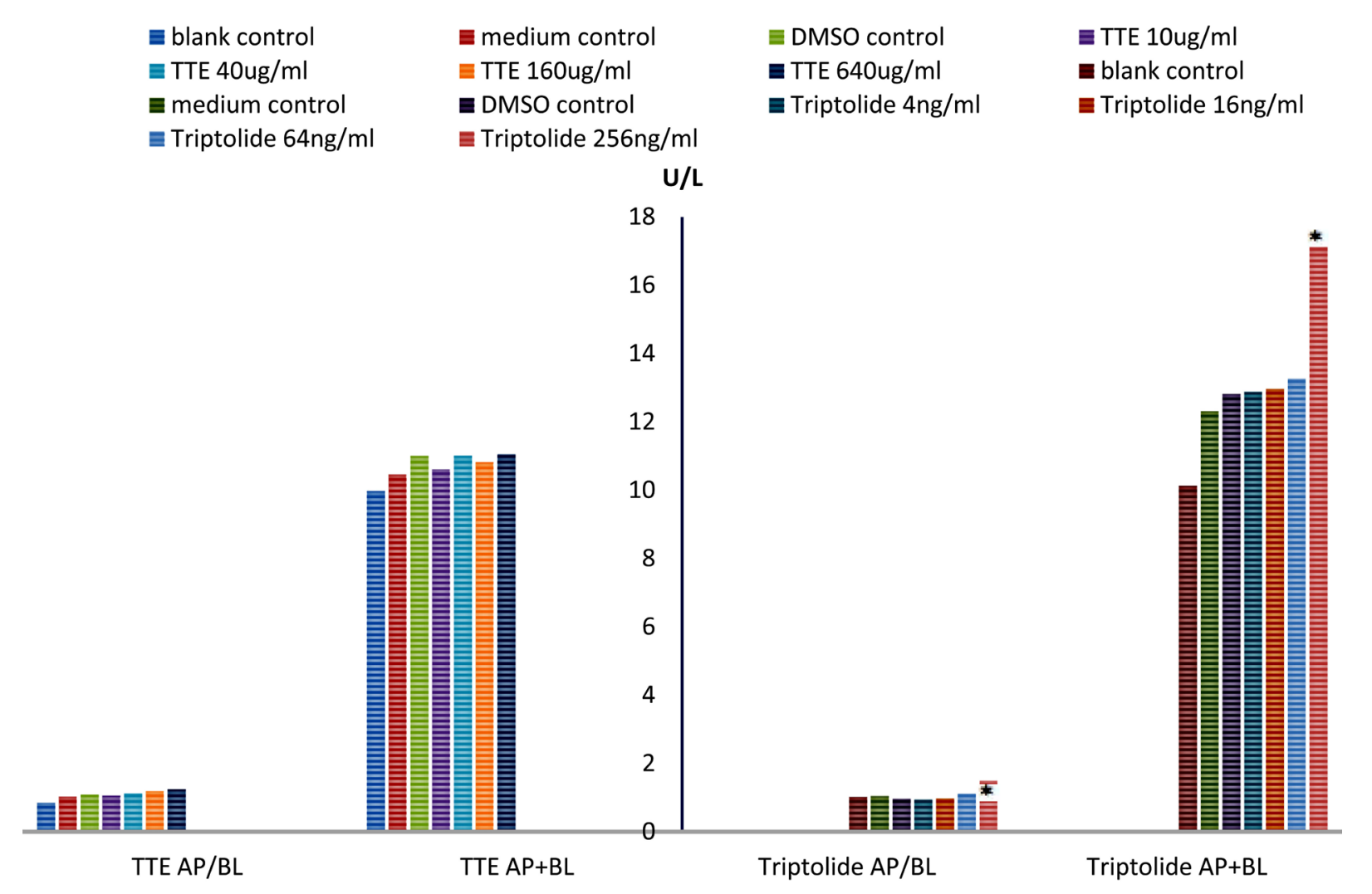

Figure 7. The effect of TTE and triptolide on the activity of NAG.

\subsection{Effect on the Morphology of HK-2 Cells}

The results of optical microscope indicated that the morphologies of the cells in the medium control group and the DMSO control group were normal. At dosages from $10 \mu \mathrm{g} \cdot \mathrm{ml}^{-1}$ to $640 \mu \mathrm{g} \cdot \mathrm{ml}^{-1}$, TTE caused various degrees of loose arrangement between cells, decreased cell dense, or even a large area of cells disappeared, abnormal ratios of nucleus to cytoplasm, cell edge indistinct, focal or massive diffuse vacuolar degeneration of the cells; pyknosis was observed at 40 $\mu \mathrm{g} \cdot \mathrm{ml}^{-1}$ and above, which exhibited statistically significant differences compared with DMSO group $(P<0.05, P<0.01)$. At dosages from $4 \mathrm{ng} \cdot \mathrm{ml}^{-1}$ to $256 \mathrm{ng} \cdot \mathrm{ml}^{-1}$, triptolide caused various degrees of vacuolar degeneration, cytoplasm rarefaction; at $256 \mathrm{ng} \cdot \mathrm{ml}^{-1}$, triptolide caused significantly reduced growth density of HK-2 cells, abnormal ratios of nucleus to cytoplasm, and eosinophils increased; compared with DMSO group, triptolide dose group at $16,256 \mathrm{ng} \cdot \mathrm{ml}^{-1}$ exhibited statistically significant differences $(P<0.05)$. The results of scanning electron microscope indicated that the HK-2 cells of the medium control and DMSO control group fused into patches, with tight cellular structures and dense microvilli on the cell surfaces. TTE at concentrations of $10 \mu \mathrm{g} \cdot \mathrm{ml}^{-1}$ and above and triptolide at concentrations of $4 \mathrm{ng} \cdot \mathrm{ml}^{-1}$ caused different levels of reduction in the number of microvilli and even disappearance of this structure; the tight junctions of the cells were depolymerized, the cell monolayer was no longer intact, the damage to the cells was aggravated with increasing dosages of the test 
substances; thus indicating that the test substances resulted in different degrees of damage to the HK-2 cells. The results are presented in Table 5 and Figure 8 \& Figure 9.

\subsection{Effect on F-Actin Expression on HK-2 Cells}

The results of fluorescence microscope indicated that the medium group and the DMSO control groups were in a compact monolayer structure, and the intracellular F-actin microfilaments formed bundles of fibers in parallel arrangements or staggered networks throughout the whole cell. TTE at concentrations of 10 $\mu \mathrm{g} \cdot \mathrm{ml}^{-1}$ and above and triptolide at concentrations of $4 \mathrm{ng} \cdot \mathrm{ml}^{-1}$ caused shrinkage of HK-2 cells, decreased cell dense; intracellular F-actin bundles became shortened and thickened to various degrees, adopted a dot-like structure, or even disappeared; the intracellular distribution of F-actin bundles changed to the cell periphery. The above changes in F-actin bundles became more severe with increasing dosages of the test substances. The above findings indicated that the test substances resulted in different extents of changes in the cytoskeletal structures of HK-2 cells at different dosages. The results are shown in Figure 10.

\section{Discussion}

Actin is present in two forms in cells, polymerized actin (F-actin) and free actin (G-actin). The dynamic changes in the intracellular contents of both actin forms regulate the remodeling of the actin cytoskeleton, which in turn affects cell morphology and cellular function [12] [13]. Studies have shown that F-actin bundles become shorter and thicker when cells are damaged, and their intracellular distribution is translocated to the microvilli and the periphery of the cells, which can lead to microvillar collapse [14]. Tight junctions (TJs) play an important role in maintaining the differences in material on the two sides of epithelial

Table 5. The effect of TTE and triptolide on pathological grading of HK-2 cell.

\begin{tabular}{|c|c|c|c|c|c|c|c|c|}
\hline \multirow{2}{*}{ group } & \multirow{2}{*}{ dose } & \multirow{2}{*}{$\mathrm{n}$} & \multicolumn{5}{|c|}{ pathological grading } & \multirow{2}{*}{$\begin{array}{l}\text { Mean } \\
\text { Rank }\end{array}$} \\
\hline & & & - & + & ++ & +++ & ++++ & \\
\hline medium control & - & 5 & 4 & 1 & 0 & 0 & 0 & 8.90 \\
\hline DMSO control & - & 5 & 5 & 0 & 0 & 0 & 0 & 7.00 \\
\hline \multirow[t]{4}{*}{ TTE } & $10 \mu \mathrm{g} \cdot \mathrm{ml}^{-1}$ & 3 & 1 & 1 & 1 & 0 & 0 & 16.00 \\
\hline & $40 \mu \mathrm{g} \cdot \mathrm{ml}^{-1}$ & 3 & 0 & 1 & 2 & 0 & 0 & $21.83^{\star}$ \\
\hline & $160 \mu \mathrm{g} \cdot \mathrm{ml}^{-1}$ & 3 & 0 & 0 & 3 & 0 & 0 & $24.50^{\star *}$ \\
\hline & $640 \mu \mathrm{g} \cdot \mathrm{ml}^{-1}$ & 3 & 0 & 0 & 0 & 2 & 1 & $31.83^{*}$ \\
\hline \multirow[t]{4}{*}{ triptolide } & $4 \mathrm{ng} \cdot \mathrm{ml}^{-1}$ & 3 & 2 & 1 & 0 & 0 & 0 & 10.17 \\
\hline & $16 \mathrm{ng} \cdot \mathrm{ml}^{-1}$ & 3 & 0 & 2 & 1 & 0 & 0 & $19.17^{\star}$ \\
\hline & $64 \mathrm{ng} \cdot \mathrm{ml}^{-1}$ & 3 & 1 & 0 & 1 & 1 & 0 & 20.83 \\
\hline & $256 \mathrm{ng} \cdot \mathrm{ml}^{-1}$ & 3 & 0 & 0 & 2 & 0 & 1 & $27.50^{*}$ \\
\hline
\end{tabular}

Note: Compared with DMSO control group, ${ }^{*} P<0.05$. 


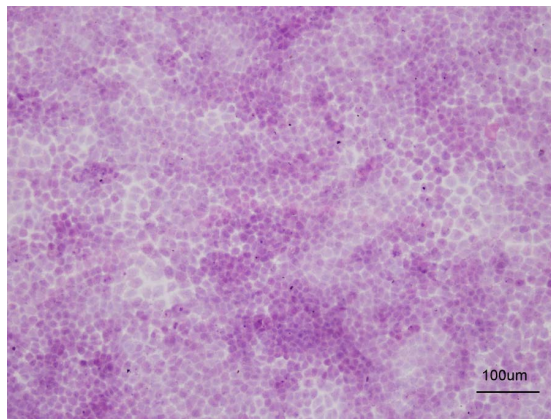

(a)

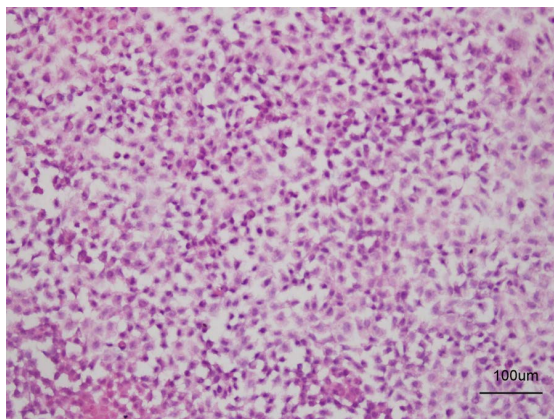

(d)

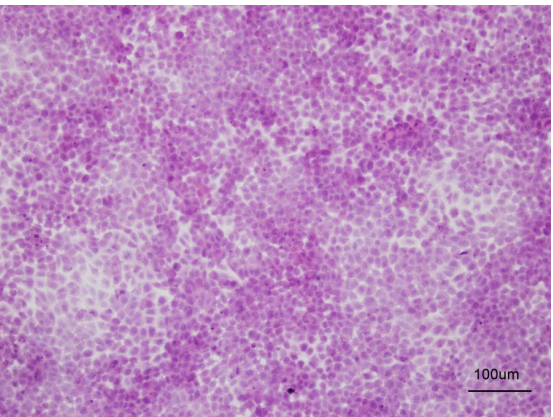

(b)

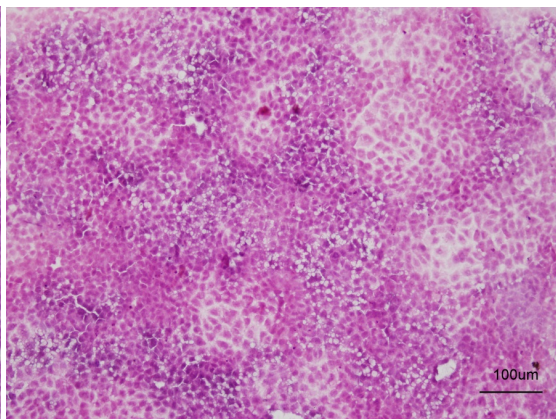

(c)

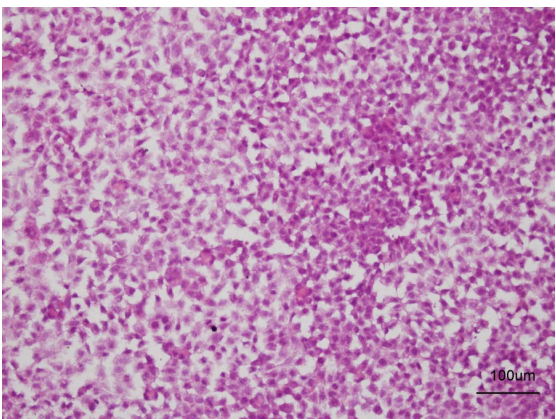

(e)

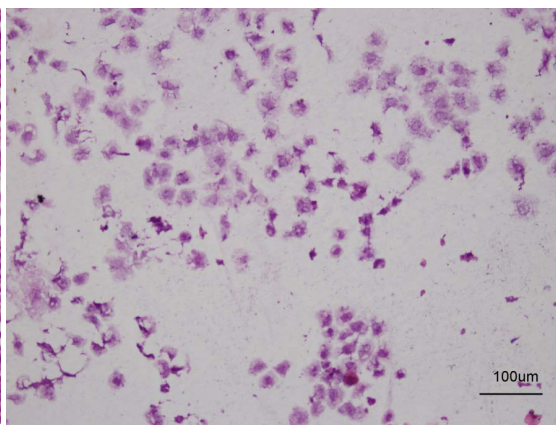

(f)

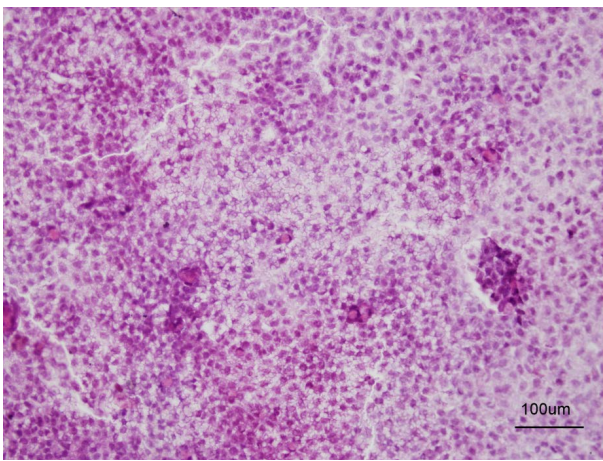

(g)

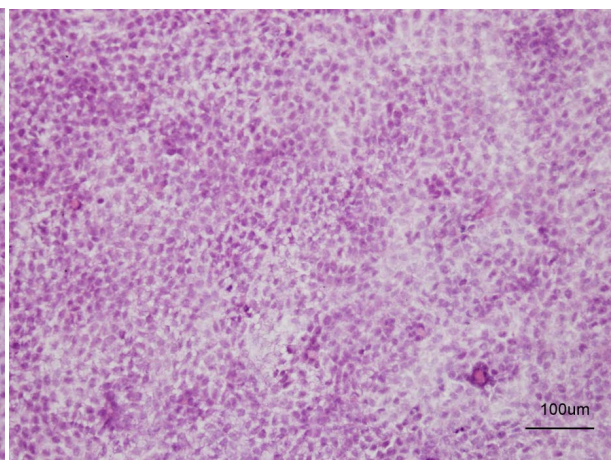

(h)

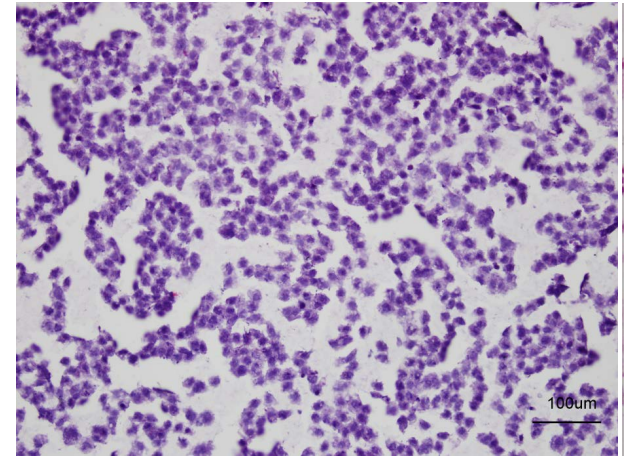

(i)

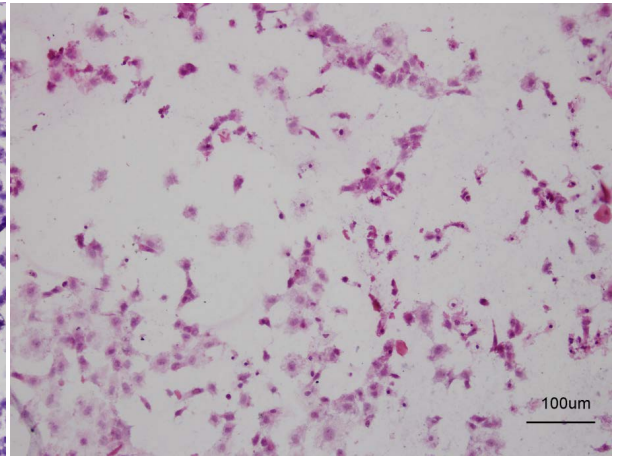

(j)

Figure 8. The effect of Tripterygium wilfordii polyglycoside (TWP) and triptolide on HK-2 cell morphology observed under optical microscope ( $\times 200, \mathrm{H} \& \mathrm{E}$ ). (Note: (a) medium control; (b) DMSO control; (c) TTE $10 \mu \mathrm{g} \cdot \mathrm{ml}^{-1}$; (d) TTE $40 \mu \mathrm{g} \cdot \mathrm{ml}^{-1}$; (e) TTE 160 $\mu \mathrm{g} \cdot \mathrm{ml}^{-1}$; (f) TTE $640 \mu \mathrm{g} \cdot \mathrm{ml}^{-1}$; (g) triptolide $4 \mathrm{ng} \cdot \mathrm{ml}^{-1}$; (h) triptolide $16 \mathrm{ng} \cdot \mathrm{ml}^{-1}$; (i) triptolide $64 \mathrm{ng} \cdot \mathrm{ml}^{-1}$; (j) triptolide $256 \mathrm{ng} \cdot \mathrm{ml}^{-1}$ ). 


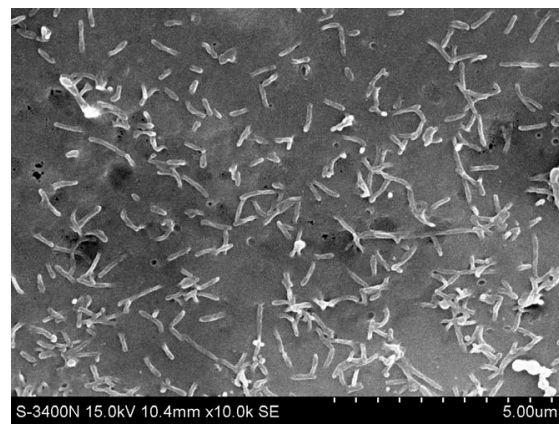

(a)

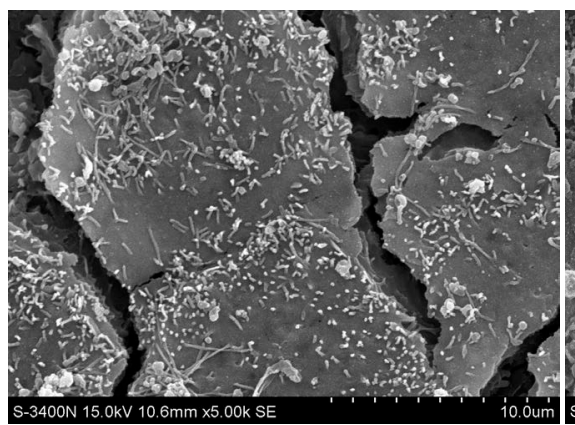

(d)

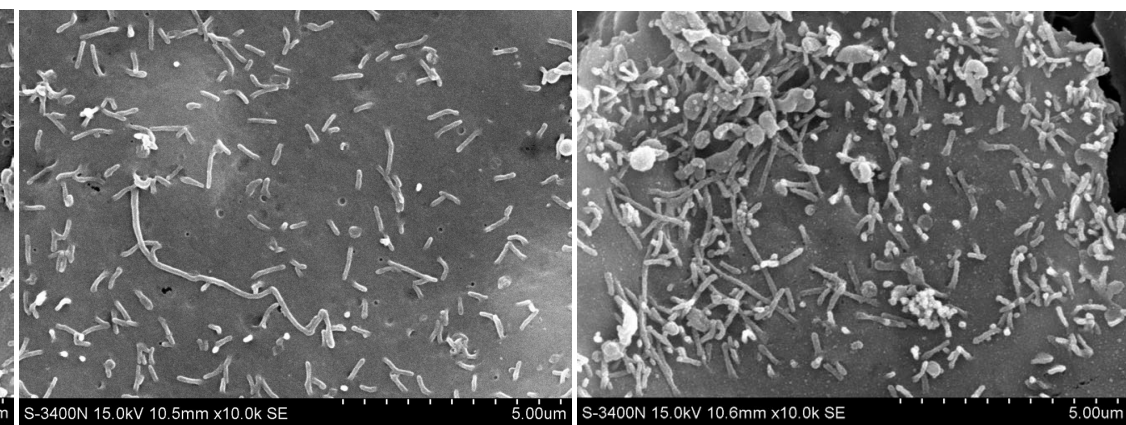

(b)

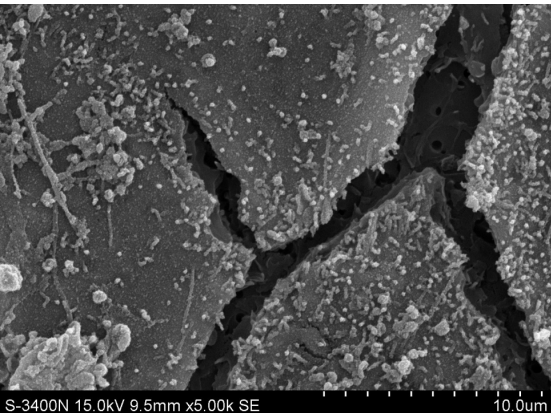

(e)

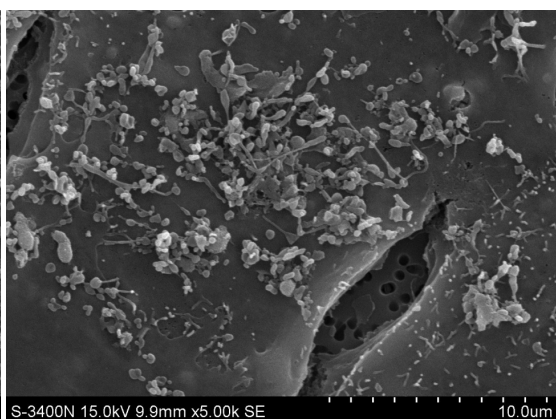

(f)

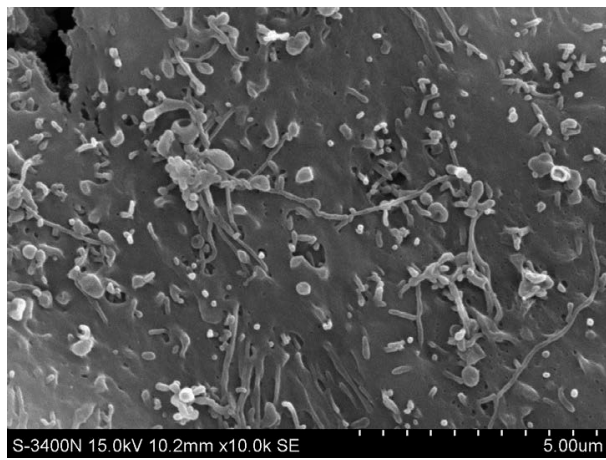

(g)

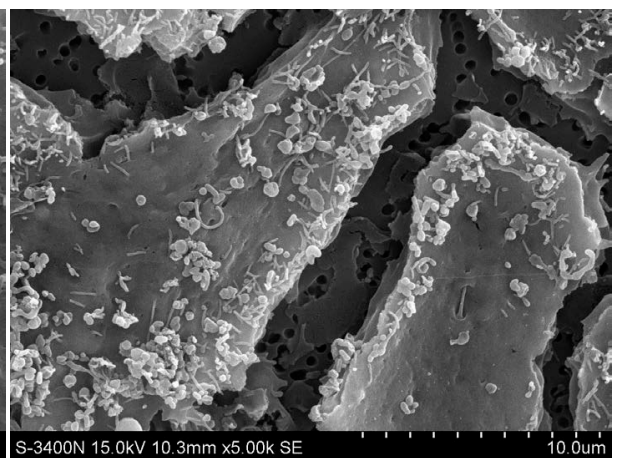

(h)

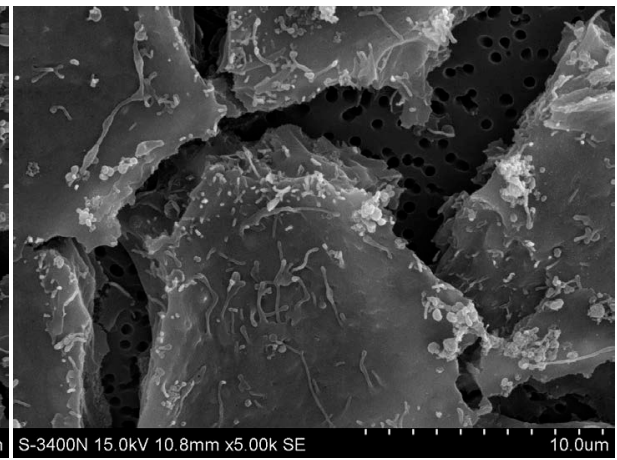

(j)

Figure 9. The effect of TTE and triptolide on HK-2 cell morphology observed under SEM. (Note: (a) medium control $\times 10.0 \mathrm{~K}$; (b) DMSO control $\times 10.0 \mathrm{~K}$; (c) TTE $10 \mu \mathrm{g} \cdot \mathrm{ml}^{-1} \times 10.0 \mathrm{~K}$; (d) TTE $40 \mu \mathrm{g} \cdot \mathrm{ml}^{-1} \times 5.0 \mathrm{~K}$; (e) TTE $160 \mu \mathrm{g} \cdot \mathrm{ml}{ }^{-1} \times 5.0 \mathrm{~K}$; (f) TTE 640 $\mu \mathrm{g} \cdot \mathrm{ml}^{-1} \times 5.0 \mathrm{~K} ;(\mathrm{g})$ triptolide $4 \mathrm{ng} \cdot \mathrm{ml}^{-1} \times 10.0 \mathrm{~K}$; (h) triptolide $16 \mathrm{ng} \cdot \mathrm{ml}^{-1} \times 5.0 \mathrm{~K}$; (i) triptolide $64 \mathrm{ng} \cdot \mathrm{ml}^{-1} \times 5.0 \mathrm{~K}$; (j) triptolide $\left.256 \mathrm{ng} \cdot \mathrm{ml}^{-1} \times 5.0 \mathrm{~K}\right)$. 


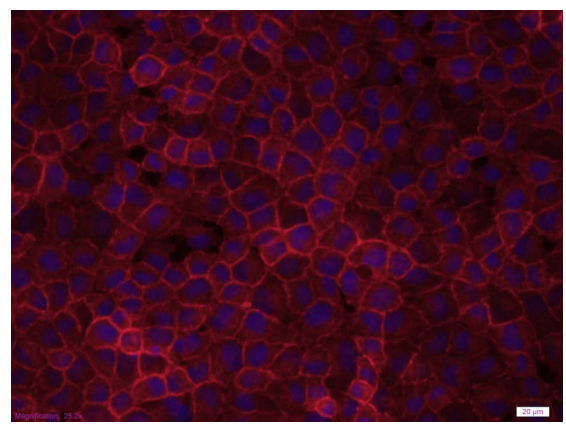

(a)

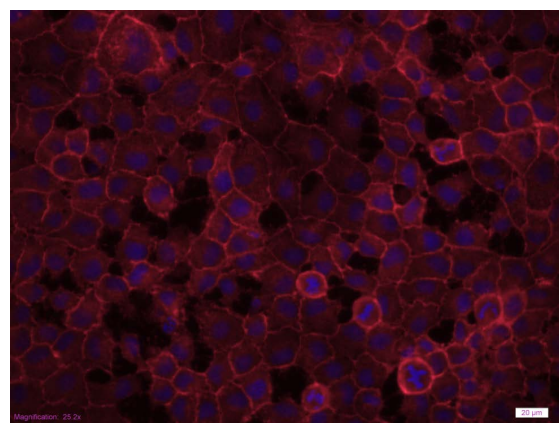

(d)

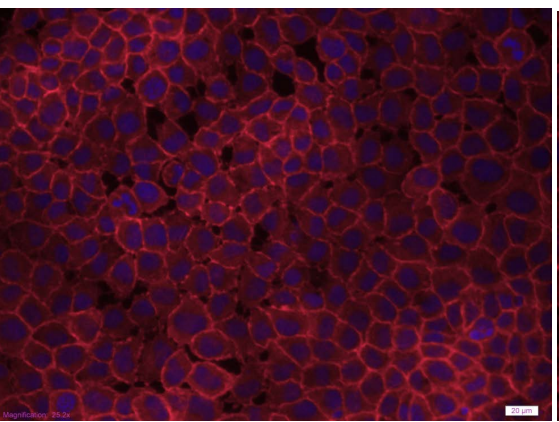

(b)

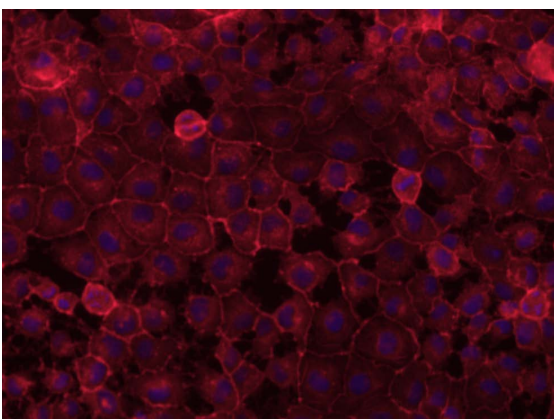

(c)

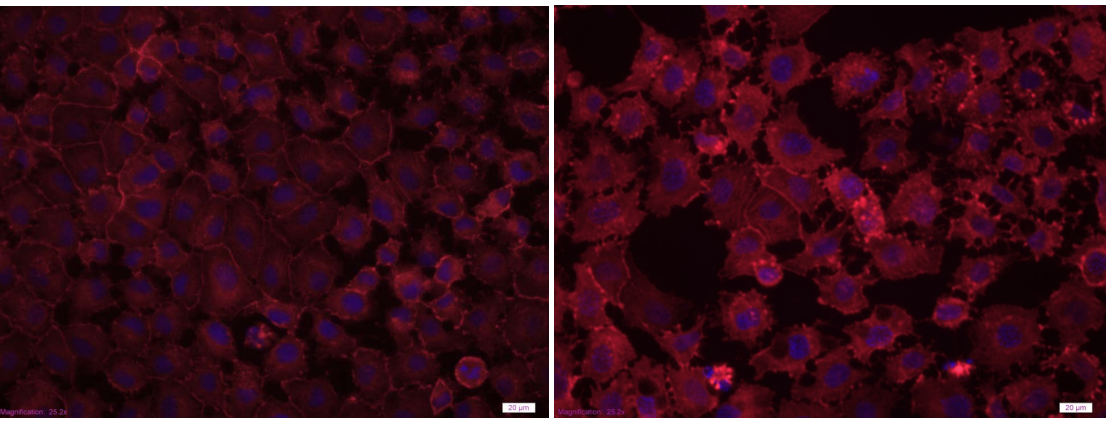

(e)

(f)

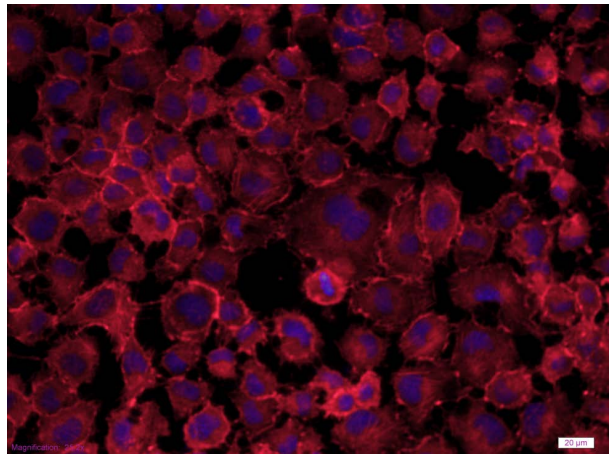

(g)

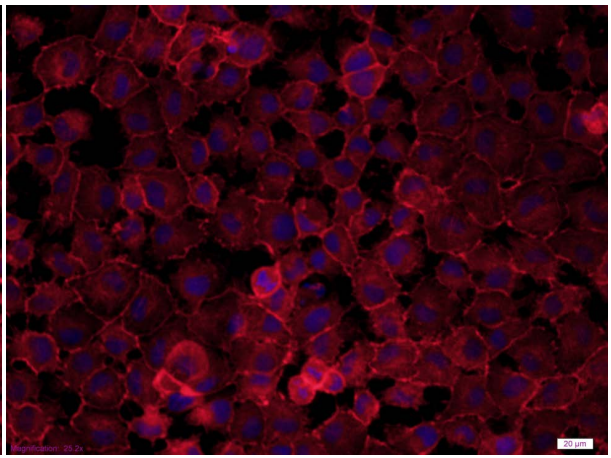

(h)

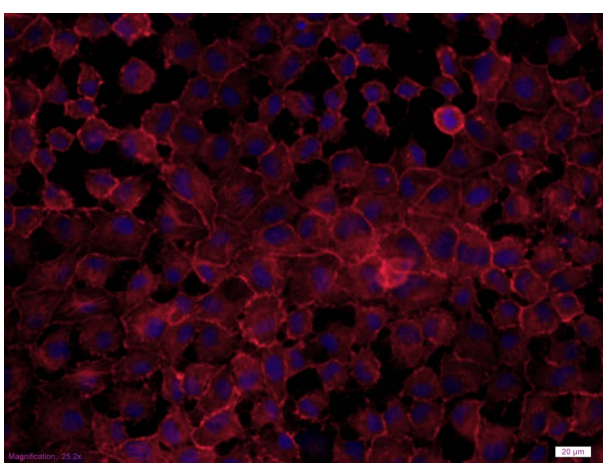

(i)

Figure 10. The effect of TTE and triptolide on HK-2 cell cytoskeleton observed under fluorescence microscope $(\times 400)$. (Note: (a) medium control; (b) DMSO control; (c) TTE $10 \mu \mathrm{g} \cdot \mathrm{ml}^{-1}$; (d) TTE $40 \mu \mathrm{g} \cdot \mathrm{ml}^{-1}$; (e) TTE $160 \mu \mathrm{g} \cdot \mathrm{ml}^{-1}$; (f) TTE $640 \mu \mathrm{g} \cdot \mathrm{ml} l^{-1}$; (g) triptolide $4 \mathrm{ng} \cdot \mathrm{ml}^{-1}$; (h) triptolide $16 \mathrm{ng} \cdot \mathrm{ml}^{-1}$; (i) triptolide $64 \mathrm{ng} \cdot \mathrm{ml}^{-1}$; (j) triptolide $256 \mathrm{ng} \cdot \mathrm{ml}^{-1}$ ). 
cell and in preserving the polarity of cells. Studies have suggested that the degradation of TJ proteins can lead to cell contraction and changes in cell permeability [15] or disruption of cell polarity, resulting in changes in the biological properties [16]. In this experiment, the morphological changes of HK-2 cells was observed via optical microscope, changes in the tight junctions and structure of microvilli was examined using scanning electron microscope, expression and localization of F-actin was observed under a fluorescence microscope. Our results confirmed that TTE at concentrations of $10-640 \mu \mathrm{g} \cdot \mathrm{ml}^{-1}$ and triptolide at concentrations of $4-256 \mathrm{ng} \cdot \mathrm{ml}^{-1}$ resulted in different extents of changes in the cytoskeletal structures of HK-2 cells cultured in a transwell chamber, with increasing dosages of the test substances, a dot-like structure of F-actin bundles increased, cell contraction resulted in a decrease in cell density, the intracellular distribution of F-actin bundles changed to the cell periphery and in irregular arrangements with TTE at concentrations of $640 \mu \mathrm{g} \cdot \mathrm{ml}^{-1}$ and triptolide at concentrations of $256 \mathrm{ng} \cdot \mathrm{ml}^{-1}$. The results of the intracellular F-actin bundles observed by fluorescence microscopy were consistent with the morphologies of the cells observed under light and electron microscopy, TTE and triptolide caused various degrees of loose arrangement between cells, decreased cell dense, or even a large area of cells disappeared, pyknosis or nucleus enlargement, abnormal ratios of nucleus to cytoplasm, focal or massive diffuse vacuolar degeneration of the cells, the tight junctions of the cells were depolymerized, different levels of reduction in the number of microvilli and even disappearance of this structure. The changes in cytoskeletal structure led to changes in cell morphology, thus, the integrity of the cell monolayer was destroyed in varying degrees, the results could be directly in the reaction FITC leakage rate, leakage of FITC experimental results showed that TTE and triptolide could lead to FITC cumulative leakage rate increased.

When renal tubular epithelial cells (RETCs) are damaged, some kidney-specific or non-specific substances in the cells are released. A number of studies have confirmed that drug-induced kidney injury can increase the release of LDH and NAG, and NAG exhibited more sensitive changes and can be used to evaluate the early damage of proximal tubules [17] [18] [19], GGT activity in the supernatant reflects the conditions of the damages to the brush-border membrane [20]. Our results confirmed that the total amount of secreted GGT and LDH exhibited a dose-dependent increase after incubation of HK-2 cells with TTE, but did not have any effect on NAG, moreover, TTE significantly increased AP/BL ratios at $160 \mu \mathrm{g} \cdot \mathrm{ml}^{-1}$ at which FITC leakage rate was $16.08 \%$, decreased AP/BL ratios at $640 \mu \mathrm{g} \cdot \mathrm{ml}^{-1}$ at which FITC leakage rate was $68.67 \%$, the above findings indicated that damage to cell integrity increased contents on the BL side and thus increased total secretion amounts and decreased AP/BL ratio. Triptolide caused a dose-dependent increase in the total secretion of GGT, LDH and NAG, an increase in the AP/BL ratio of GGT, LDH and NAG at $256 \mathrm{ng} \cdot \mathrm{ml}^{-1}$, whereas TTE did not induce significant changes in NAG secretion. 


\section{Conclusion}

In summary, through observations of cellular structures (cell monolayer integrity) and cellular functions (secretion of active enzymes), this study demonstrated that TTE and triptolide caused various degrees of damage to human renal proximal tubular epithelial cells, which is characterized by an increased FITC rate, an affected secretion of GGT,LDH and NAG, as well as the changes in cytoskeleton and cell morphology; the injury degree of triptolide at the level of NG is similar to that of microgram level of TTE. To some extent, the toxicity intensity of triptolide is much higher than that of TTE.

\section{Acknowledgements}

This work was supported by ICMM Grant ZZ2006106, GH2017-01-02 and NSFC Grant 90709043.

\section{References}

[1] Guo, Y. and Tan, K. (2007) Toxicity of Tripterygium wilfordii and Its Research Situation. Journal of Chinese Medicinal Materials, 30, 112-117.

[2] Sun, X., Zhang, S., Tian, C., et al. (2001) Tripterygium wilfordii and Its Safety. Chinese Journal of New Drugs, 11, 539-543.

[3] Xue, J., Jia, X., Tan, X., et al. (2010) Study on Chemical Constituents and Toxicity of Tripterygium wilfordii. China Journal of Traditional Chinese Medicine and Pharmacy, 25, 730-731.

[4] Yao, J., Sun, Y., Luo, S., et al. (2010) Advances in Clinical Application of Tripterygium wilfordii Glycosides. Chinese Journal of New Drugs and Clinical Remedies, 3 , 26-29.

[5] Feng, Q., Luan, Y. and Sun, R. (2013) Research Progress of Tripterygium wilfordii Toxicity Based on Efficacy and Material Basis. Chinese Journal of Pharmacovigilance, 10, 88-91.

[6] Chang, J., Shi, L. and Song, H. (2012) Clinical Study of Tripterygium wilfordii in the Treatment of the Senile Diabetic Nephropathy. World Clinical Drugs, 33, 96-98.

[7] Li, J., Xia, S. and Song, S. (2012) Research Progress of Diterpenoids from Tripterygium and the Study on New Drugs. Journal of Shenyang Pharmaceutical University, 29, 901-908.

[8] Liu, M., Dong, J., Yang, Y., et al. (2005) Research Progress on Triptolide. Journal of Chinese Materia Medica, 30, 170-174.

[9] Ding, H., Wu, J., Tong, J., et al. (2004) Study on Acute Toxicity of Triptolide and Its Mechanism. Journal of Chinese Medicinal Materials, 27, 115-118.

[10] Wang, A. and Luo, G. (2008) Toxicity of Tripterygium wilfordii. Hubei Journal of Traditional Chinese Medicine, 30, 60-61.

[11] Bi, K. (2000) Analysis of 20 Cases of Acute Renal Failure Caused by Tripterygium wilfordii. Chinese Journal of Modern Applied Pharmacy, 17, 502.

[12] Papakonstanti, E.A. and Stournaras, C. (2008) Cell Responses Regulated by Early Reorganization of Actin Cytoskeleton. FEBS Letters, 582, 2120-2127. https://doi.org/10.1016/j.febslet.2008.02.064

[13] Prasain, N. and Stevens, T. (2009) The Actin Cytoskeleton in Endothelial Cell Phe- 
notypes. Microvascular Research, 77, 53-63.

https://doi.org/10.1016/j.mvr.2008.09.012

[14] Molitoris, B.A. (1997) Putting the Actin Cytoskeleton into Perspective: Pathophysiology of Ischemic Alterations. American Journal of Physiology, 272, F430-F433.

[15] Laukoetter, M.G., Bruewer, M. and Nusrat, A. (2006) Regulation of the Intestinal Epithelial Barrier by the Apical Junctional Complex. Current Opinion in Gastroenterology, 22, 85-89. https://doi.org/10.1097/01.mog.0000203864.48255.4f

[16] Ichikawa-Tomikawa, N., Sugimoto, K., Satohisa, S., et al. (2011) Possible Involvement of Tight Junctions, Extracellular Matrix and Nuclear Receptors in Epithelial Differentiation. Journal of Biomedicine and Biotechnology, 2011, Article ID: 253048.

[17] Johnson, A.C., Becker, K. and Zager, R.A. (2010) Parenteral Iron Formulations Differentially Affect MCP-1, HO-1, and NGAL Gene Expression and Renal Responses to Injury. American Journal of Physiology-Renal Physiology, 299, F426-F435. https://doi.org/10.1152/ajprenal.00248.2010

[18] D’Amico, G. and Bazzi, C. (2003) Urinary Protein and Enzyme Excretion as Markers of Tubular Damage. Current Opinion in Nephrology and Hypertension, 12, 639-643. https://doi.org/10.1097/00041552-200311000-00011

[19] Bazzi, C., Petrini, C., Rizza, V., et al. (2002) Urinary N-acetyl-beta-glucosaminidase Excretion Is a Marker of Tubular Cell Dysfunction and a Predictor of Outcome in Primary Glomerulonephritis. Nephrology Dialysis Transplantation, 17, 1890-1896. https://doi.org/10.1093/ndt/17.11.1890

[20] Pei, X. and Xu, Z. (2005) Effects of Cadmium on Calcium Cadherin in Renal Tubular Epithelial Cells. Chinese Journal of Industrial Medicine, 18, 266-268. 